\title{
Modelling the environmental impacts of future offshore fish farms in the inner Danish waters
}

\author{
Marie Maar*, Janus Larsen, Karsten Dahl, Bo Riemann \\ Department of Bioscience, Aarhus University, Frederiksborgvej 399, PO Box 358, 4000 Roskilde, Denmark
}

\begin{abstract}
There are plans to increase offshore aquaculture production of rainbow trout in the inner Danish waters, with an expected annual release into the environment of $100 \mathrm{t} \mathrm{N}$ and $12.8 \mathrm{t}$ P per farm. We applied 3D modelling to estimate the spatial and temporal effects of 2 hypothetical offshore fish farms on water quality, sediment fluxes and nutrient transports in the Samsø Belt area. The model results showed that water quality (mainly dissolved inorganic $\mathrm{N}$ and primary production) was affected in open waters during the production period, leaving no traces 1 mo after the production period. Changes in bottom water oxygen levels and Secchi depths were not considered important for the system. Sediment organic content and nutrient fluxes increased from reference conditions locally below the fish cages. The sediment did not recover from the impact between the production periods, especially at the site with lowest resuspension. There was a gross transport of nutrients into the coastal water areas corresponding to $21 \% \mathrm{~N}$ and $16 \% \mathrm{P}$ of the farm inputs, but this only resulted in minor changes in water quality. However, the additional nutrients from the fish farms counteract implemented nutrient reductions from other sources which aim to improve the ecological status, and the excessive nutrients were shown to reach several protected Natura 2000 sites. Future implementation of fish farms in the area requires detailed spatial planning, optimisation of farm design and nutrient compensation by marine measures, e.g. blue mussel farming.
\end{abstract}

KEY WORDS: Fish farm $\cdot$ Eutrophication $\cdot$ Nutrient addition $\cdot$ Rainbow trout $\cdot$ Ecological impacts

\section{INTRODUCTION}

Economic activities that depend on the sea, also known as the 'blue economy', are today seen as one of the most promising means to boost growth, employment opportunities and competitiveness in Europe (European Commission 2012). Globally, coastal and marine aquaculture is a fast-growing sector and provides $25 \%$ of the marine fish supply to the world market (Naylor et al. 2000, Duarte et al. 2009, FAO 2016). In Europe, however, aquaculture production has stagnated, probably due to restrictions on sites and environmental issues (Bostock et al. 2010). Waste products from finfish farms contribute to eutrophication problems in coastal areas. Fast-sinking feed pellets and faeces from fish farms enrich the sediments

${ }^{*}$ Corresponding author: mam@bios.au.dk with organic material in the vicinity of the farms, which can increase the oxygen demand and affect benthic communities (Christensen et al. 2000, Tovar et al. 2000, Cromey et al. 2002). Dissolved waste products (i.e. inorganic nutrients) promote primary production, increase phytoplankton biomass and decrease water clarity, with negative effects on the bottom vegetation (Dalsgaard \& Krause-Jensen 2006, Holmer et al. 2008). These environmental pressures are expected to be less at offshore sites due to larger dispersal of waste products and fewer interactions with coastal flora and fauna (Holmer 2010). Hence, offshore fish farming is predicted to increase in the near future (Troell et al. 2009, Holmer 2010).

Offshore fish farms are typically located $>3 \mathrm{~km}$ from the coast at depths of $>50 \mathrm{~m}$ and are considered

(C) The authors 2018. Open Access under Creative Commons by Attribution Licence. Use, distribution and reproduction are unrestricted. Authors and original publication must be credited. 
beneficial to the fish due to higher water quality and to the environment because of the lower impact compared to coastal sites (Holmer 2010). However, larger quantities of waste per farm can be expected, as the scale of the offshore operations is most likely larger than that of existing nearshore installations (Troell et al. 2009, Holmer 2010). Hence, there is a risk that organic enrichment from solid waste exceeds the assimilation capacity by the benthic environment and accumulates over time at greater depths (Troell et al. 2009, Valdemarsen et al. 2012). As offshore waters have lower background nutrient concentrations than coastal areas, phytoplankton growth is more nutrient-limited and may show a more pronounced response. Another risk is that some of the nutrients and the stimulated phytoplankton biomass from fish farms are advected into coastal areas (WildAllen et al. 2010, Ferreira et al. 2014). In Europe, this effect may violate the goal of achieving a good ecological status according to the European Union (EU) Water Framework Directive (WFD; Directive 2000/60 EC) obtained through reductions in, for example, land-based nutrient loadings (Riemann et al. 2016). Thus, careful site selections of fish farms based on knowledge of the environmental effects are important to obtain an efficient mitigation effect on nutrient loadings at basin scale. Moreover, this knowledge can further be used in multi-criteria marine spatial planning together with other socio-economic activities (Douvere 2008, Silva et al. 2011).

Aquaculture in Denmark has existed since the 1970s. The most common aquaculture species is rainbow trout Oncorynchus mykiss. The production season starts in April by transfer of fish from inland fish farms to sea cages. The transferred fish typically have an individual weight of 0.7 to $1 \mathrm{~kg}$, and the fish are harvested in November, when they have a weight of 2 to $4 \mathrm{~kg}$ (Nielsen et al. 2015). Presently, 19 aquaculture production sites are found in Danish marine waters, with annual net production per farm ranging from 300 to $2300 \mathrm{t}$ (Møhlenberg 2013). Total production of all 19 fish farms is around $11 \mathrm{kt}(\sim 600 \mathrm{t}$ per farm) (http://agrifish.dk/). Further expansion in the coastal zone is considered difficult due to eutrophication problems and protection by the WFD. Instead, according to the Danish Food and Agriculture Strategy (Miljø- og Fødevareministeriet 2015), a >100\% increase in fish production is planned through the establishment of offshore fish farms. Each of the planned offshore farms is expected to produce around $2200 \mathrm{t}$ fish annually, with a release of about $100 \mathrm{t}$ of $\mathrm{N}$ into the environment. The fate and ecological impact of this release is presently unknown. In this context, 3D ecological models are important tools to estimate fine-scale fluxes, transformations and fate of waste products from fish farms and to conduct scenarios beyond the scope of observational methods (Skogen et al. 2009, Wild-Allen et al. 2010, Hadley et al. 2016). In this study, we applied 3D modelling to estimate spatial and temporal effects of 2 hypothetical offshore fish farms on water quality, nutrient transports and sediment fluxes in the Danish Samsø Belt.

\section{METHODS}

\section{Study area}

The Samsø Belt area is located between the Kattegat, the Great Belt and the Little Belt (Fig. 1). Salty bottom water enters from the Kattegat-North Sea and is separated from the brackish surface water from the Belt Sea-Baltic Sea by an almost permanent halocline at 6 to $15 \mathrm{~m}$ depth (Andersson \& Rydberg 1988, Jørgensen et al. 2014). A seasonal thermocline occurs from April to October and largely coincides with the halocline. The system is affected by eutrophication, often with hypoxia events in deeper areas, and summer primary production is mainly Nlimited (Richardson \& Christoffersen 1991). The area is divided into open waters (defined as $>1$ nautical mile [nm] from the coastline) and administrative coastal water areas which have been split into eastern and western coastal water areas with respect to the farm locations (Fig. 1A). Many legislative regulations are in function in the coastal waters. The coastal waters are to meet the targets set by the WFD, and targets for all marine waters are in the process of being adopted in accordance with the EU Marine Strategic Framework Directive (2008/56/EC). Further, the area hosts many Natura 2000 sites. The sites are appointed to protect several habitats: reef (1170), shallow bays and inlets (1160) and sandbanks (1110), as well as harbour porpoise and seals appointed according to the Habitats Directive (92/43/EEC) and birds appointed according to the Birds Directive (2009/147/EEC).

\section{Model system}

The ecological model was coupled to a 3D offline advection module in the Flexsem framework using an unstructured computational mesh (Larsen et al. 2017, Petersen et al. 2017). The velocity fields, averaged over every 15 min for the year 2009, were obtained 

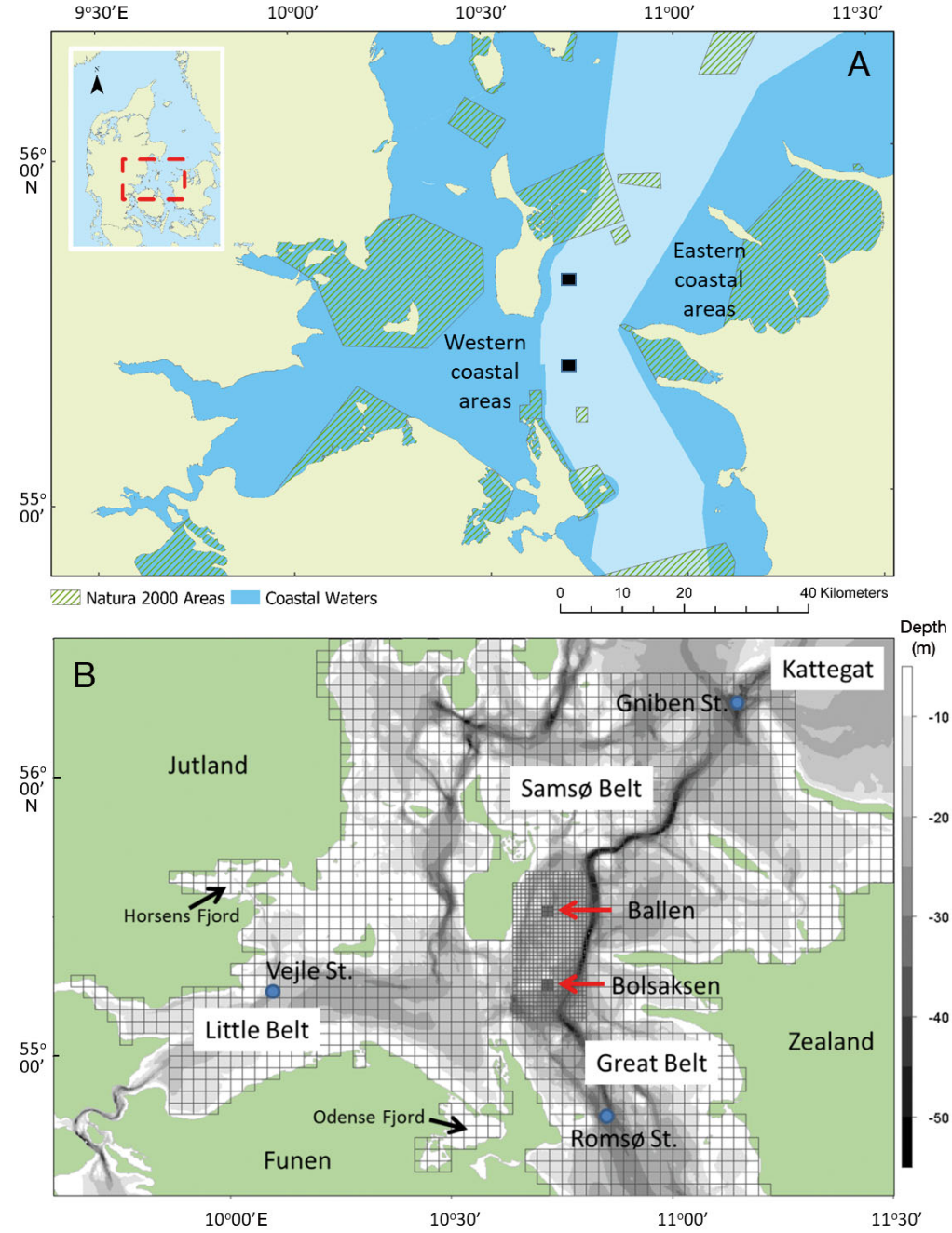

Fig. 1. Area around Samsø Belt in Denmark. (A) Eastern and western coastal water areas (blue) administrated according to the Water Framework Directive, Natura 2000 sites (hatched lines), and potential locations of 2 fish farms (Ballen and Bolsaksen, black squares) located in open waters (light blue). (B) Model mesh, bathymetry and the monitoring stations (blue dots)

from the 3D ocean circulation HIROMB-BOOS model (HBM) (She et al. 2007, Berg \& Poulsen 2012). The offline advection module was implemented on the same $1800 \times 1800 \mathrm{~m}$ horizontal grid (rectangular cells) as for HBM. The unstructured mesh approach allowed a gradual refinement of the computational mesh around the fish farms, which otherwise would have required more complicated nesting techniques in the structured model. The potential fish farms were placed offshore, i.e. $>1 \mathrm{~nm}$ from land outside the administrative coastal water areas (Fig. 1A). The horizontal resolution was increased to $600 \times 600 \mathrm{~m}$ in the area around the fish farms $(6 \times 12$ grid cells) and further to $200 \times 200 \mathrm{~m}$ in the farm vicinity $(<1800 \mathrm{~m})$ (Fig. 1B) using linear interpolation of the velocity fields from HBM. The vertical resolution was in $z$-coordinates, i.e. the separation be- tween computational cells in the vertical was defined at fixed depths, whereas the top layer had a free surface to allow for water level changes. The layer thickness was set to $2 \mathrm{~m}$ in the top layer, followed by $1 \mathrm{~m}$ in the upper $30 \mathrm{~m}$ and $10 \mathrm{~m}$ in the bottom cell from 31 to $40 \mathrm{~m}$ depth. The open boundaries were located at the entrance to the Kattegat, the Great Belt and the Little Belt (Fig. 1B). Open boundary data and initial data of physical and pelagic biogeochemical state variables were obtained from a previous model run of the North Sea-Baltic Sea using HBM and the ecological regional ocean model (ERGOM) (Maar et al. 2016). River discharges of freshwater and nutrients from 9 sources were provided by the Department of Bioscience, Aarhus University (Windolf et al. 2011, Maar et al. 2016). Atmospheric forcing of air temperature, wind speed and light radiation from 2009 were provided by an operational atmospheric model (Brandt et al. 2001). Atmospheric deposition of nutrients was added to the top layer of the model, with an average of $0.15 \mathrm{mmol} \mathrm{NH}_{4} \mathrm{~m}^{-2} \mathrm{~d}^{-1}$ and $0.001 \mathrm{mmol} \mathrm{PO}_{4} \mathrm{~m}^{-2} \mathrm{~d}^{-1}$ (Hansen 2013, HELCOM 2013).

\section{Pelagic ecosystem model}

ERGOM (Neumann 2000, Maar et al. 2011, Wan et al. 2012) simulates the cycling of N, P and Si. The 11 state variables describe concentrations of 4 nutrients $\left(\mathrm{NO}_{3}, \mathrm{NH}_{4}, \mathrm{PO}_{4}, \mathrm{SiO}_{2}\right), 3$ functional groups of phytoplankton (diatoms, flagellates, cyanobacteria), micro- and mesozooplankton, detritus and oxygen (Fig. 2). The model considers the processes of nutrient uptake, $\mathrm{N}_{2}$-fixation by cyanobacteria, growth, grazing, respiration, recycling, mortality, settling, nitrification and denitrification. Concentrations of organic matter were estimated in $\mathrm{N}$ units and converted to $\mathrm{C}$ and $\mathrm{P}$ using the Redfield $\mathrm{C}: \mathrm{N}: \mathrm{P}$ ratio of 106:16:1. Silicate is only taken up by diatoms and released again through respiration and mortality assuming an Si:N ratio of 0.94 . Phytoplankton biomass was expressed as the sum of the 3 phytoplankton groups and converted to chl a concentrations using a factor of $2 \mathrm{mg} \mathrm{chl} \mathrm{a}(\mathrm{mmol} \mathrm{N})^{-1}$ (Neumann 2000). Diatoms, flagellates and cyanobacteria are grazed by micro- and mesozooplankton. Microzoo- 


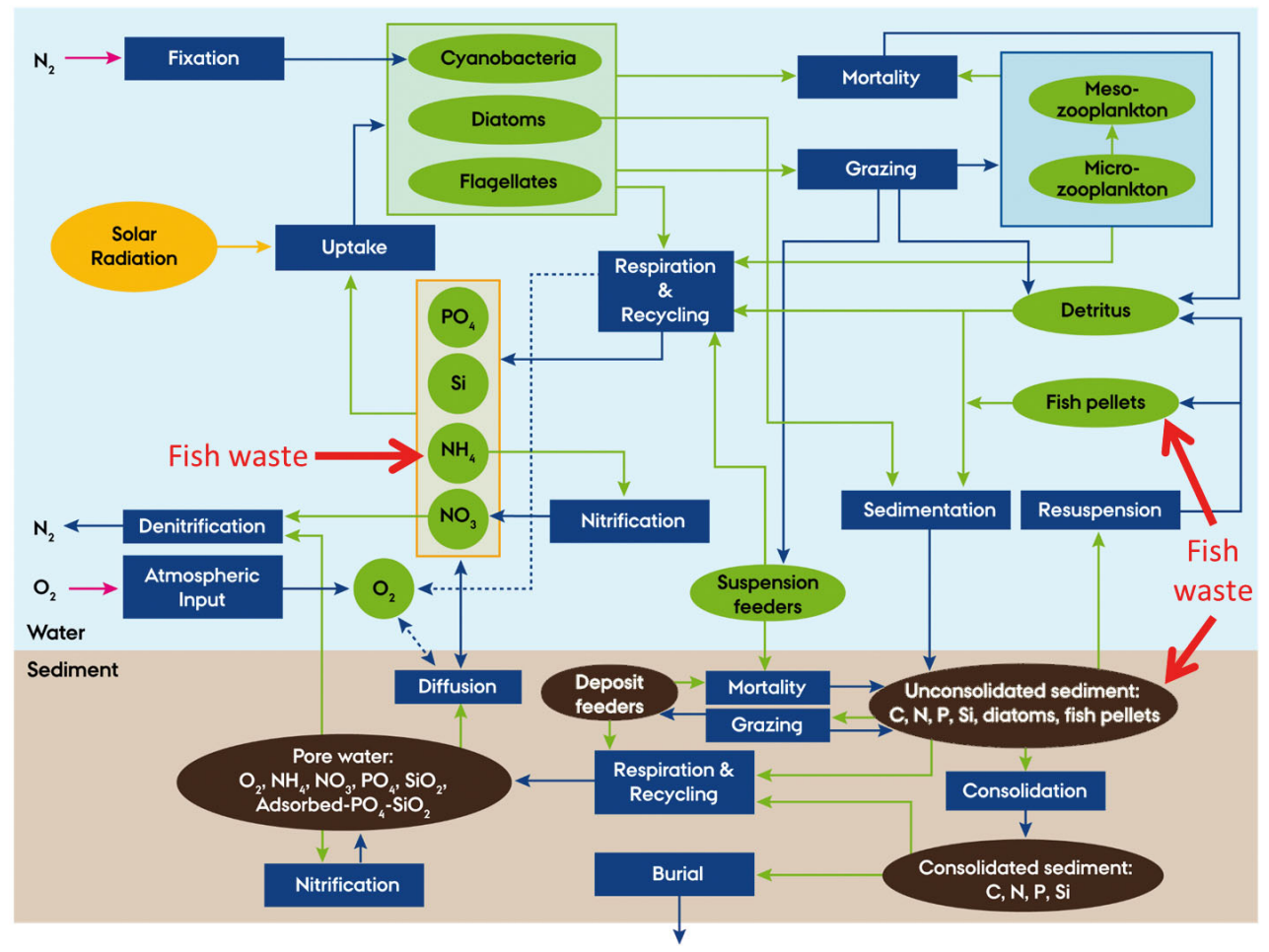

Fig. 2. ERGOM model. Blue boxes are processes, green circles and ovals are state variables in the water column; brown ovals are state variables in the sediment; red arrows show the input of nutrients and fish pellets from the fish farms

plankton mortality rates include intra-guild predation and predation by mesozooplankton (Maar et al. 2014). Mesozooplankton biomass-specific mortality rate was obtained from previous field estimates and linearly interpolated to daily values, with the highest values during spring and autumn (Kiørboe \& Nielsen 1994, Petersen et al. 2017). The light attenuation coefficient $\left(k_{\mathrm{d}}, \mathrm{m}^{-1}\right)$ was estimated as the sum of the contributions by background (water and coloured dissolved organic matter), phytoplankton and detritus (Maar et al. 2011). ERGOM was calibrated and validated against monitoring data from the North Sea-Baltic Sea in previous studies (Maar et al. 2011, 2014, 2016).

\section{Benthic ecosystem model}

ERGOM is a 2-way pelagic model coupled to a sediment biogeochemical model through sedimentation and resuspension of organic matter and diffusive fluxes of nutrients and oxygen (Petersen et al. 2017). Pelagic detritus and diatoms sediment into an organic detritus pool and a dead diatom pool, respectively, in the unconsolidated top layer of the sediment (Fig. 2, Table S1 in the Supplement at www.intres.com/articles/suppl/q010p115_supp.pdf). Organic matter in the unconsolidated sediment can be resuspended, respired or gradually transferred to the consolidated sediment layer. During a resuspension event, organic matter is transferred to the respective bottom water pools. Mass conservation in the model therefore requires that the resuspended matter follows the Redfield ratio. The sediment types are mainly sand, silty sand, mud and clay. Resuspension occurs at bottom currents $>0.10 \mathrm{~m} \mathrm{~s}^{-1}$ corresponding to the bottom shear threshold of $0.026 \mathrm{~N} \mathrm{~m}^{-2}$ assuming a bottom roughness length of $3 \times 10^{-4} \mathrm{~m}$ (Christiansen et al. 1997). Resuspension due to wave action is not explicitly described by the model and was implemented using a constant loss rate from sandy sediments according to field studies (Christiansen et al. 1997, Jansen et al. 2003). In the consolidated sediment, the organic matter has variable nutrient ratios $(\mathrm{C}: \mathrm{N}: \mathrm{P})$ due to the higher recycling rates for nutrients than the respiration rate for $\mathrm{C}$. The $\mathrm{N}: \mathrm{C}$ ratio of the detritus is used as a proxy for lability assuming that older detritus with a lower $\mathrm{N}: \mathrm{C}$ ratio is degraded more slowly (Tett 1998, Maar et al. 2010). Recycled nutrients $\left(\mathrm{NH}_{4}, \mathrm{PO}_{4}\right.$ and $\left.\mathrm{SiO}_{2}\right)$ in the sediment porewater are exchanged with the bottom water through diffusion. A fraction of the recycled $\mathrm{NH}_{4}$ is lost in a coupled nitrification-denitrification process. Under oxidised conditions, $\mathrm{PO}_{4}$ and $\mathrm{SiO}_{2}$ are retained in the 
sediment by adsorption to $\mathrm{Fe}$ or $\mathrm{Mn}$ and released when the sediment becomes reduced. Benthic suspension feeders ingest phytoplankton, detritus and fish particular waste in the bottom water, whereas deposit feeders ingest freshly deposited diatoms, detritus and fish particular waste in the sediment (Maar \& Hansen 2011, Timmermann et al. 2012). Suspension feeders (e.g. blue mussels) were set to be more resistant to hypoxia compared to the more sensitive deposit feeders (Timmermann et al. 2012). The ingested matter is recycled into inorganic nutrients through respiration and excretion or into detritus through defecation and death (Table S2). Initial values of benthos and sediment organic matter content were based on previous measurements in the area (Rysgaard et al. 2001, Maar \& Hansen 2011, Hansen 2012). The spin-up time was $5 \mathrm{yr}$ to achieve more realistic spatial distributions, which were used as initial conditions in the reference and scenario simulations. The benthic model was previously validated by comparing bottom water concentrations of nutrients and oxygen with monitoring data in the Kattegat (Petersen et al. 2017).

\section{Validation of the model}

The model results were validated against data from 3 monitoring stations: Gniben (50 m depth), Romsø (38 $\mathrm{m}$ depth) and Vejle (21 m depth) (Fig. 1B). Data were provided by the ODA database hosted by Aarhus University. The validation was performed for surface $(1 \mathrm{~m})$ and bottom salinity and temperature; surface and bottom concentrations of dissolved inorganic nitrogen (DIN = ammonium and nitrate), $\mathrm{PO}_{4}$ and $\mathrm{SiO}_{2}$; surface chl a concentrations; bottom oxygen; and Secchi depth. Secchi depths (m) were calculated from $k_{\mathrm{d}}$ derived from the model and data using Secchi $=1.614 \times k_{\mathrm{d}}{ }^{-0.936}($ Neumann et al. 2015), whereas direct Secchi depth measurements (and not $k_{\mathrm{d}}$ ) were available at Romsø stn. Depth-integrated primary production data were available from Romsø and Vejle stns as monthly means from 2001 to 2008 (Lyngsgaard et al. 2014). Model performance was assessed using seasonal correlation analysis (Pearson $\mathrm{R}^{2}$, significance level of $\alpha=0.05$ ) and the percentage model bias $\left[\mathrm{PMB}=\left(\operatorname{mean}_{\text {model }}-\operatorname{mean}_{\text {data }}\right) / \operatorname{mean}_{\text {data }} \times\right.$ $100 \%$ ]. The PMB is the average deviation between model results and observations, and a deviation of $|\mathrm{PMB}|<40 \%$ is considered a good model performance (Allen et al. 2007). A thorough validation of nutrient and oxygen fluxes at the sediment-water interface was not possible due to lack of data from the same year. Instead, model fluxes from 2009 were compared with the only available measurements from 1999, 2000 and 2002 from 6 shallow $(<10 \mathrm{~m}$ deep) monitoring stations in Horsens Fjord and Odense Fjord. These years were characterised by more hypoxia events than 2009 (Hansen 2013), and some differences between the data and model results were expected.

\section{Fish farms}

Rainbow trout fish farms were artificially launched at 2 locations considered as potential sites by aquaculture producers. The northern farm was located in the water area called Ballen and the southern farm in Bolsaksen, both at water depths of 19 to $20 \mathrm{~m}$ (Fig. 1A). The production season varied from April to November (Nielsen et al. 2015). The seasonal distribution of the feed supply and hence waste production in the model was dome shaped (Fig. 3), since the fish stock is low at the beginning of the season, increases during the summer period and needs less food for growth at the end of the season (Nielsen et al. 2015). Total waste from rainbow trout was separated into solid and dissolved fractions based on a waste production model (www.aquawaste.dk) applied to marine farming of rainbow trout (J. Dalsgaard \& Pedersen 2011, Dalsgaard \& Pedersen 2016). The model was based on controlled laboratory experiments with 2 types of fish feed, where the $\mathrm{N}$ and $\mathrm{P}$ contents were measured in the fish faecal pellets. The dissolved waste fraction was estimated as the total amount of added fish feed minus the solid waste and fish content. The coefficient of variation $(\mathrm{CV}=$ $\mathrm{SD} / \mathrm{mean}$ ) was 7 to $21 \%$ for the estimated content in solid waste (Dalsgaard \& Pedersen 2016). We assumed a feed quotient ( $\mathrm{t}$ of fish feed to produce $1 \mathrm{t}$ of fish biomass) of 1.2 and a feed loss of $1.5 \%$ applied to feed pellets from BIOMAR Efico-939 (6-8 $\mathrm{mm})$ in the waste production model (Nielsen et al. 2015). The dissolved waste fractions were 84 and $44 \%$ of total $\mathrm{N}$

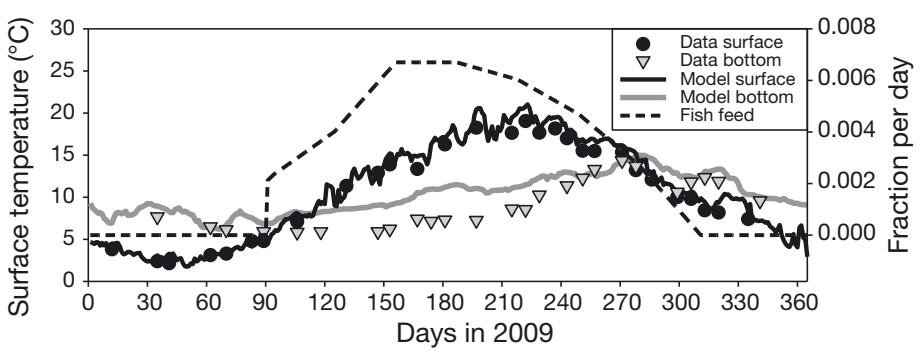

Fig. 3. Surface and bottom temperature at Romsø stn. The daily fraction of total fish feed is shown on the right axis 
Table 1. Amount of dissolved (N, P) and solid (C, N, P) waste products per ton of produced fish and total amount in the scenarios (S25, S100) estimated by the waste production model. na: not applicable

\begin{tabular}{|lccc|}
\hline & $\begin{array}{c}\text { Waste } \\
\left(\mathrm{kg} \mathrm{t} f i s h^{-1}\right)\end{array}$ & $\begin{array}{c}\mathrm{S} 25 \\
(\mathrm{t})\end{array}$ & $\begin{array}{c}\mathrm{S} 100 \\
(\mathrm{t})\end{array}$ \\
\hline Fish production & na & 560 & 2250 \\
Total N & 44.4 & 25 & 100 \\
Dissolved N & 37.5 & 21.1 & 84.4 \\
Solid N & 6.9 & 3.9 & 15.6 \\
Total P & 5.7 & 3.2 & 12.8 \\
Dissolved P & 2.5 & 1.4 & 5.7 \\
Solid P & 3.2 & 1.8 & 7.1 \\
Solid C & 76.5 & 44 & 173 \\
\hline
\end{tabular}

and $\mathrm{P}$, respectively (Table 1). The released nutrients $\left(\mathrm{NH}_{4}, \mathrm{PO}_{4}\right)$ were added as a source to the pelagic model (Fig. 2) in the fish farm areas at the depth range of 0 to $10 \mathrm{~m}$ for fish cages. Solid matter (fish faecal pellets and feed waste) was assumed to settle directly into the unconsolidated sediment layer due to high sinking velocities (Cromey et al. 2002). The settled waste could be resuspended, degraded or gradually transferred to the consolidated sediment layer following the same equations as for detritus. After resuspension, we assumed that the solid waste was fragmented into smaller particles with a lower sinking velocity (Magill et al. 2006, Piedecausa et al. 2009) (see Table S1). The solid fish waste was included as 3 new benthic state variables $(C, N, P)$ and 3 new pelagic state variables (C, N, P) (Fig. 2). The applied C:N ratio of 11.1 (weight basis) was estimated based on the macronutrient composition of fish faeces and feed waste multiplied by the $\mathrm{C}$ content of carbohydrates and lipids (Gnaiger \& Bitterlich 1984) and the $\mathrm{C}$ and $\mathrm{N}$ content of proteins (Rouwenhorst et al. 1991).

\section{Model scenarios}

The reference run (REF) was a standard simulation of 2009 without fish farms. The year 2009 was a relatively warm and dry year, and annual total $\mathrm{N}$ and total P inputs from freshwater sources to the study area were $4704 \mathrm{t} \mathrm{N}$ and $189 \mathrm{t} \mathrm{P}$ according to monitoring data (Windolf et al. 2011). This input was 27 and $13 \%$ lower, respectively, of total $\mathrm{N}$ and total $\mathrm{P}$ compared to the period 2004 to 2009, whereas the nutrient input from the North Sea and the Baltic Sea was close $(<4 \%)$ to average values (Petersen \& Hjorth 2010). Hence, the relatively high nutrient contribu- tions from fish farms in 2009 were assumed to represent a worst-case scenario with respect to the year-toyear variability of environmental impacts. In the first scenario, S25, the introduced fish farms corresponded to the size of an average coastal farm, with a net production of $560 \mathrm{t}$ fish and a release of $25 \mathrm{t} \mathrm{N}$ and $3.2 \mathrm{tP}$ (Table 1). In the second scenario, S100, the fish farms corresponded to the size of a standard offshore farm (4 times the coastal farm size), with a net production of $2250 \mathrm{t}$ fish and a release of $100 \mathrm{t} \mathrm{N}$ and $12.8 \mathrm{t} \mathrm{P}$ (Table 1). Fish cages within each farm were placed in 5 grid cells (size $200 \times 200 \mathrm{~m}$ ) within an area of $600 \times$ $600 \mathrm{~m}$ (9 grid cells, $\left.0.36 \mathrm{~km}^{2}\right)$. Hence, the maximum $\mathrm{N}$ and $P$ contributions from the 2 fish farms were 4.3 and $13.5 \%$, respectively, of the annual freshwater sources to the area in S100. For the fish production period (April to October), the nutrient contributions increased to $18.8 \%(\mathrm{~N})$ and $37.5 \%(\mathrm{P})$ of the freshwater sources. The year 2009 was simulated with 1 fish production cycle and continued 1 more year without fish farms to evaluate the temporal recovery of the sediment. The model estimated changes in environmental indicators (nutrients, chl $a$, primary production, zooplankton biomass and production, bottom water oxygen, Secchi depths) and sediment contents and fluxes due to fish farms relative to REF. Only changes $>1 \%$ were considered an important impact. This criterion was chosen to be more sensitive than standard analytical techniques and corresponded to $4-10 \%$ of the methodology detection levels of nutrient and chl a concentrations and bottom oxygen (applied to a critical level of $2 \mathrm{mg} \mathrm{O}_{2} \mathrm{l}^{-1}$ ) in the monitoring program. The same approach has been used in previous environmental impact assessments of fish farms in Denmark (Kaas et al. 2017). There are no detection levels defined for primary production, $k_{\mathrm{d}}$ and zooplankton biomass and production in the monitoring program, and the same threshold of $1 \%$ was applied.

The accumulated transport of nutrients from the offshore fish farms to the coastal water areas (Fig. 1A) was estimated as gross transport, i.e. the total amount of nutrient inflow, and as net transport, i.e. the amount that stays or is lost (e.g. by denitrification, burial or incorporation into biomass) in the coastal water areas, calculated as the difference between inflow and outflow during the fish production period. A sensitivity study was conducted to estimate the importance of benthic nutrient fluxes from deposited solid fish waste on gross nutrient transports into the coastal water areas. This was done by setting the solid fish waste to zero and, hence, only considering the dissolved fractions of fish waste in S100 relative to REF. 


\section{RESULTS}

\section{Physical background data}

There was a seasonal surface heating and temperature stratification of the water column from April to October (Fig. 3). In addition, the water column was almost permanently stratified by a pycnocline, with mean $( \pm \mathrm{SD})$ surface salinity values of $19 \pm 3$ and bottom salinity values of $30 \pm 4$ at the 3 monitoring stations (data not shown). Model results of temperature and salinity showed high seasonal correlations with monitoring data, and model performance was overall good, although bottom temperature was slightly overestimated by the model (Table 2). Surface velocity was mainly in a northerly direction, with mean $( \pm \mathrm{SD})$ velocity of $0.53 \pm 0.33 \mathrm{~m} \mathrm{~s}^{-1}$ at both Ballen and Bolsaksen (Fig. 4A,B). Bottom velocity was either northeasterly or southwesterly at Ballen and either northerly or southerly at Bolsaksen due to tidal in-
Table 2. Model validation results ( $\mathrm{R}^{2}$ and percentage model bias [PMB]) for the 3 stations. DIN: dissolved inorganic nitrogen; (-): no data; ns: not significant

\begin{tabular}{|c|c|c|c|c|c|c|}
\hline & \multicolumn{3}{|c|}{$-\mathrm{R}^{2}-$} & \multicolumn{3}{|c|}{$-\mathrm{PMB}(\%)-$} \\
\hline & Gniben & Romsø & Vejle & Gniben & Romsø & Vejle \\
\hline \multicolumn{7}{|l|}{ Surface } \\
\hline Temperature & 0.99 & 0.99 & 0.96 & 8 & 9 & 6 \\
\hline Salinity & 0.80 & 0.90 & 0.77 & -18 & -13 & -15 \\
\hline DIN & 0.81 & 0.96 & 0.92 & -23 & -20 & -15 \\
\hline $\mathrm{PO}_{4}$ & 0.80 & 0.87 & 0.90 & -14 & 12 & 1 \\
\hline $\mathrm{SiO}_{2}$ & 0.71 & 0.69 & 0.55 & 3 & -5 & -18 \\
\hline Chl a & 0.66 & 0.82 & 0.83 & -35 & -28 & -19 \\
\hline Primary production & - & 0.85 & 0.88 & - & 25 & 26 \\
\hline Secchi depth & 0.49 & ns & 0.81 & 10 & 20 & 38 \\
\hline \multicolumn{7}{|l|}{ Bottom } \\
\hline Temperature & 0.86 & 0.88 & 0.91 & 28 & 23 & 16 \\
\hline Salinity & 0.78 & 0.62 & 0.65 & -10 & -16 & -25 \\
\hline DIN & ns & ns & ns & -1 & -3 & 32 \\
\hline $\mathrm{PO}_{4}$ & $\mathrm{~ns}$ & ns & ns & -25 & -8 & -10 \\
\hline $\mathrm{SiO}_{2}$ & ns & ns & ns & -31 & -16 & -1 \\
\hline $\mathrm{O}_{2}$ & 0.73 & 0.33 & 0.61 & 8 & 11 & 5 \\
\hline
\end{tabular}

fluence (Fig. 4C,D). Mean ( \pm SD) bottom velocity was $50 \%$ higher at Ballen with $0.08 \pm 0.05 \mathrm{~m} \mathrm{~s}^{-1}$ compared to $0.05 \pm 0.03 \mathrm{~m} \mathrm{~s}^{-1}$ at Bolsaksen.
Fig. 4. Annual average (2009) of $(A, B)$ surface and $(\mathrm{C}, \mathrm{D})$ bottom velocity direction and magnitude of currents at $(\mathrm{A}, \mathrm{C})$ Ballen and $(B, D)$ Bolsaksen
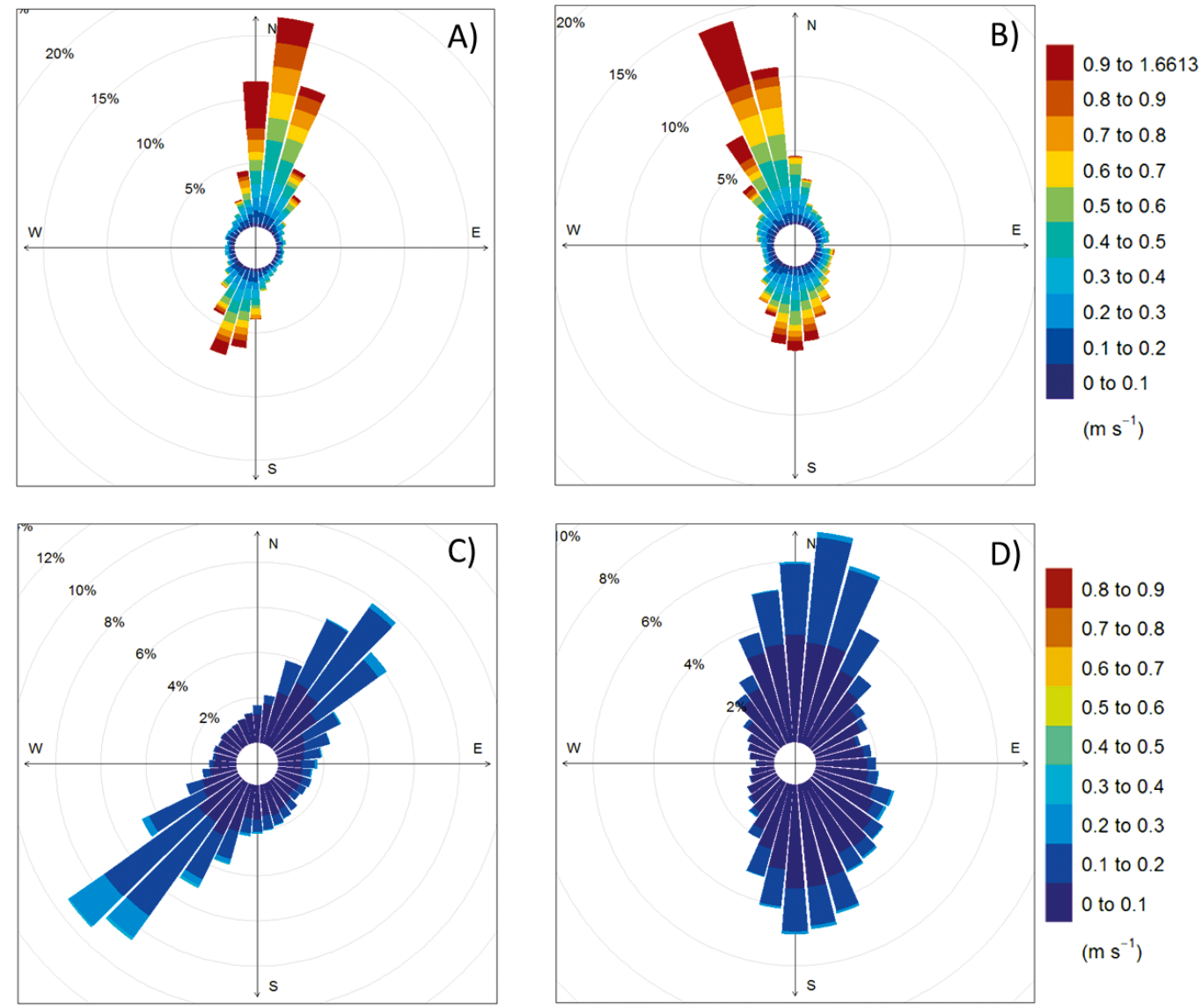

0.8 to 0.9

0.7 to 0.8

0.6 to 0.7

0.5 to 0.6

0.4 to 0.5

0.3 to 0.4

0.2 to 0.3

0.1 to 0.2

0 to 0.1

$\left(\mathrm{m} \mathrm{s}^{-1}\right)$ 


\section{Validation of ecological variables}

Model performance was good for all ecological variables at all stations (Table 2). Model correlations with data were generally high for surface ecological variables and bottom oxygen, except for Secchi depth at Romsø stn (Table 2). In contrast, bottom nutrients showed no correlations due to little seasonal variability compared to surface values. Surface nutrients were highest in winter followed by depletion from February to October and replenishment in winter, and this pattern was well captured by the model (Fig. 5A-I). The model generally reproduced the seasonal pattern of chl a concentration, but tended to underestimate it during the early spring (February) and late autumn (November) blooms (Fig. 5J-L). Primary production showed high correlation with monthly data, with around $25 \%$ overestimation (Table 2). Secchi depths varied from 3 to $12 \mathrm{~m}$ and were lowest during the early spring and late autumn blooms and highest during the summer and winter months (Fig. 5M-O). Bottom oxygen was lowest (100 to $150 \mathrm{mmol} \mathrm{m}^{-3}$ ) in autumn but was overestimated by the model at the deep

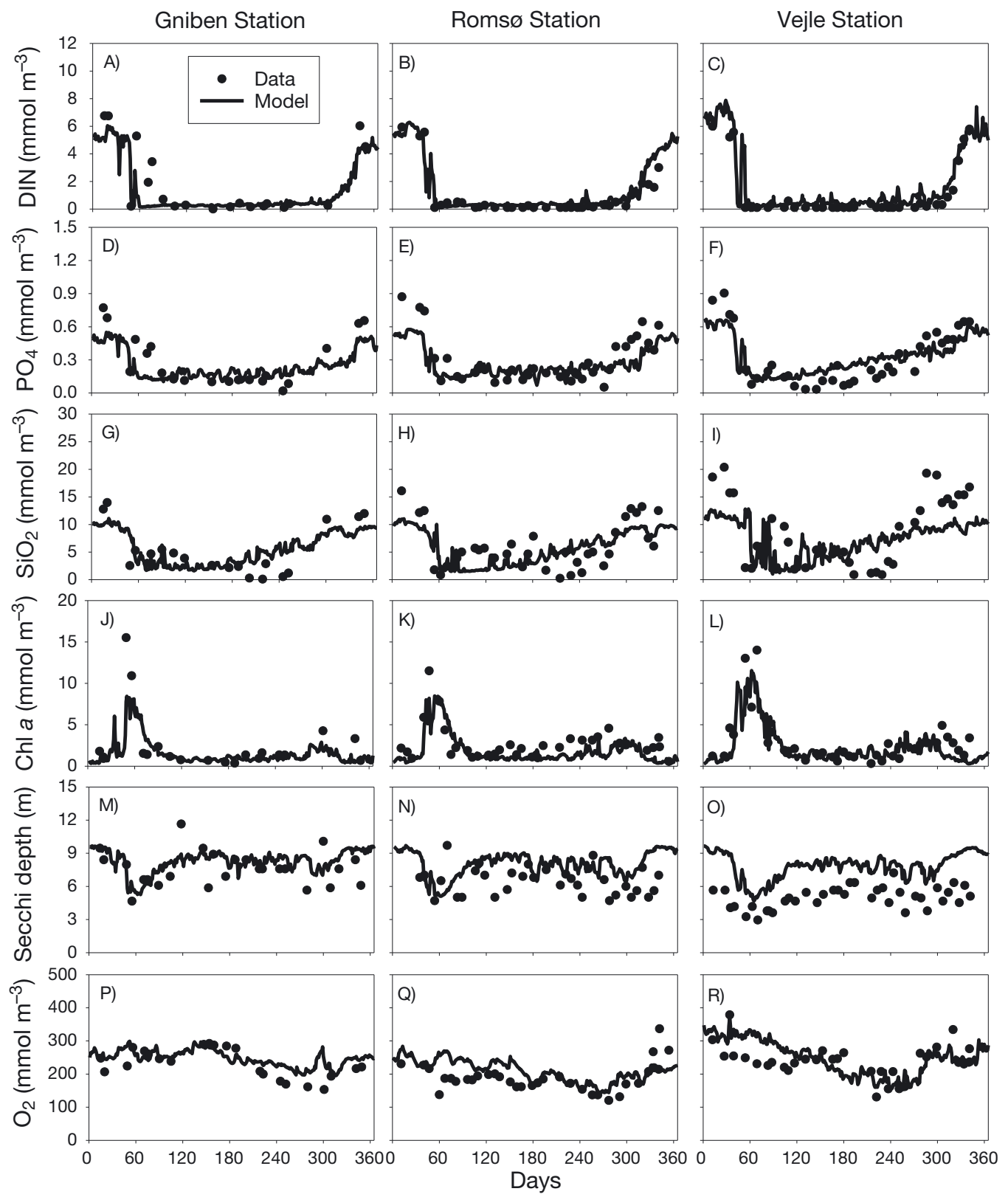

Fig. 5. Model validation of surface (1 m) (A-C) dissolved inorganic nitrogen (DIN), $\mathrm{PO}_{4}, \mathrm{SiO}_{2},(\mathrm{~J}-\mathrm{L}) \mathrm{chl} a_{1}(\mathrm{M}-\mathrm{O})$ Secchi depth and $(\mathrm{P}-\mathrm{R})$ bottom oxygen at the 3 monitoring stations in 2009 
Gniben stn (Fig. 5P-R). Modelled seasonal bottom fluxes of nutrients and oxygen were similar to monitoring data from previous years except from February to April, where sediment data showed higher nutrient uptake (negative fluxes) combined with less uptake or even release (positive fluxes) of oxygen (Fig. 6). Furthermore, the observed high $\mathrm{PO}_{4}$ release in August with hypoxia events did not occur for the model year 2009 (Fig. 6C).
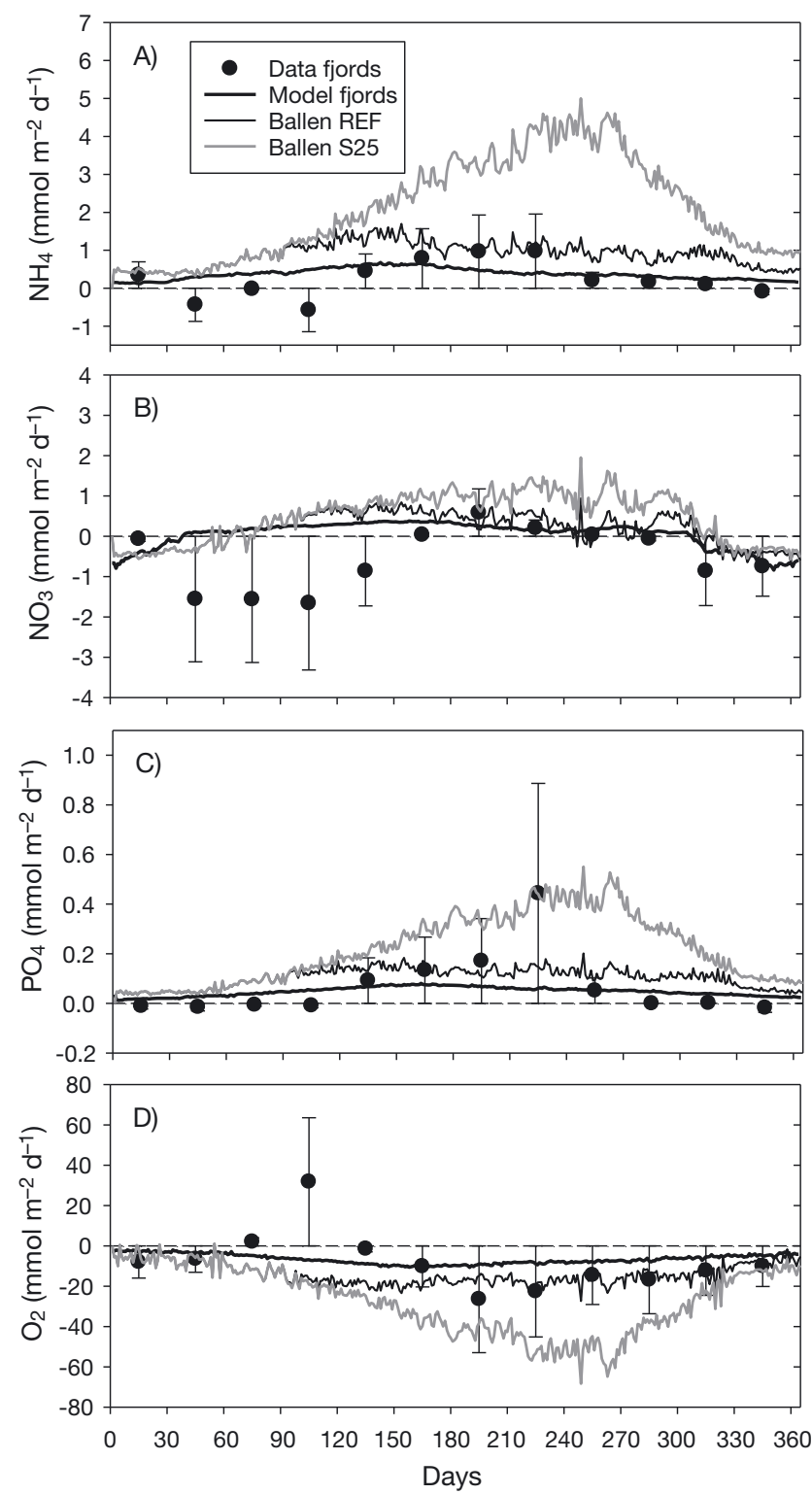

Fig. 6. Comparison of sediment-water fluxes of (A) $\mathrm{NH}_{4}$, (B) $\mathrm{NO}_{3}$, (C) $\mathrm{PO}_{4}$ and (D) $\mathrm{O}_{2}$ between monitoring data (monthly average \pm SD) for 1999, 2000 and 2003 with severe hypoxia and model data (2009) from 6 shallow stations in Horsens Fjord and Odense Fjord. Results from Ballen reference run (REF) and Scenario 25 (S25) are also shown. Positive fluxes indicate release, and negative fluxes indicate uptake by the sediment

\section{Environmental effects of fish farms in the water column}

The water column was stratified from around 5 to $12 \mathrm{~m}$ depth at Ballen in July in the model (Fig. 7A). Modelled vertical profiles (exemplified at Ballen S100 compared to REF) showed high changes in DIN concentrations in the upper $10 \mathrm{~m}$ coinciding with enhanced primary production (Fig. 7B,C). However, the change in DIN concentration was highest near the bottom $\left(<1.85 \mathrm{mmol} \mathrm{m}^{-3}\right)$ due to increased nutrient fluxes from the sediment. Changes in chl a concentrations were highest at 6 to $10 \mathrm{~m}$ depth with up to $0.03 \mathrm{mg} \mathrm{m}^{-3}$, were less at the surface (due to higher dispersal) and decreased gradually towards the bottom (Fig. 7B). Changes in zooplankton production were highest at the surface $\left(0.24 \mathrm{mg} \mathrm{m}^{-3} \mathrm{~d}^{-1}\right)$ and decreased gradually towards the bottom (Fig. 7C). Hence, the horizontal impact range for nutrients, chl a concentrations and primary production was highest at the surface (0 to $5 \mathrm{~m}$ ) due to stronger advection, but the highest responses were found below the surface layer (>5 m). The environmental impact was always higher in S100 compared to S25, and the impact was $>1 \%$ only for DIN and primary production in S25 relative to REF (Fig. 8). In the following, the environmental impact is considered for $\mathrm{S} 100$ at the 5-6 $\mathrm{m}$ depth layer relative to REF. Maximum changes in pelagic variables were observed in June and July and also in April for primary production, whereas bottom water oxygen showed maximum change in August (Table 3). The highest change was found for DIN, with up to $89 \%\left(0.32 \mathrm{mmol} \mathrm{m}^{-3}\right)$ near the farms and a rapid decline as it spread both north- and southwards up to ca. $30 \mathrm{~km}$ from the farms (Table 3, Fig. 8C). $\mathrm{PO}_{4}$ concentrations changed $<4.7 \%\left(0.009 \mathrm{mmol} \mathrm{m}^{-3}\right)$ relative to REF and mainly in the vicinity of the farms (Table 3, Fig. 8F). Chl a concentrations changed $<2 \%\left(0.03 \mathrm{mg} \mathrm{m}^{-3}\right)$ mainly from April to August with a more local impact range than for DIN (Table 3, Fig. 8I), whereas primary production increased up to $13.5 \%$ in April and $13.0 \%$ (11.5 $\mathrm{mg} \mathrm{C} \mathrm{m}^{-3} \mathrm{~d}^{-1}$ ) in July with a similar impact range as for DIN (Fig. 8L). Total zooplankton (microand mesozooplankton) production increased up to $1.8 \%\left(0.19 \mathrm{mg} \mathrm{C} \mathrm{m} \mathrm{m}^{-3} \mathrm{~d}^{-1}\right)$ in July with the same impact range as for DIN (Fig. 8O). In contrast, zooplankton biomass, Secchi depth and bottom water oxygen changed $<1 \%$ and therefore were not considered important changes from reference conditions (Table 3$)$. The effects were not visible $(<1 \%)$ for all variables in November after the fish production period. 
Fig. 7. Vertical profiles of (A) average temperature and salinity in July at Ballen and $(B, C)$ maximum difference between Scenario 100 and reference run in July for (B) dissolved inorganic nitrogen (DIN) and chl a concentrations and (C) primary and zooplankton production

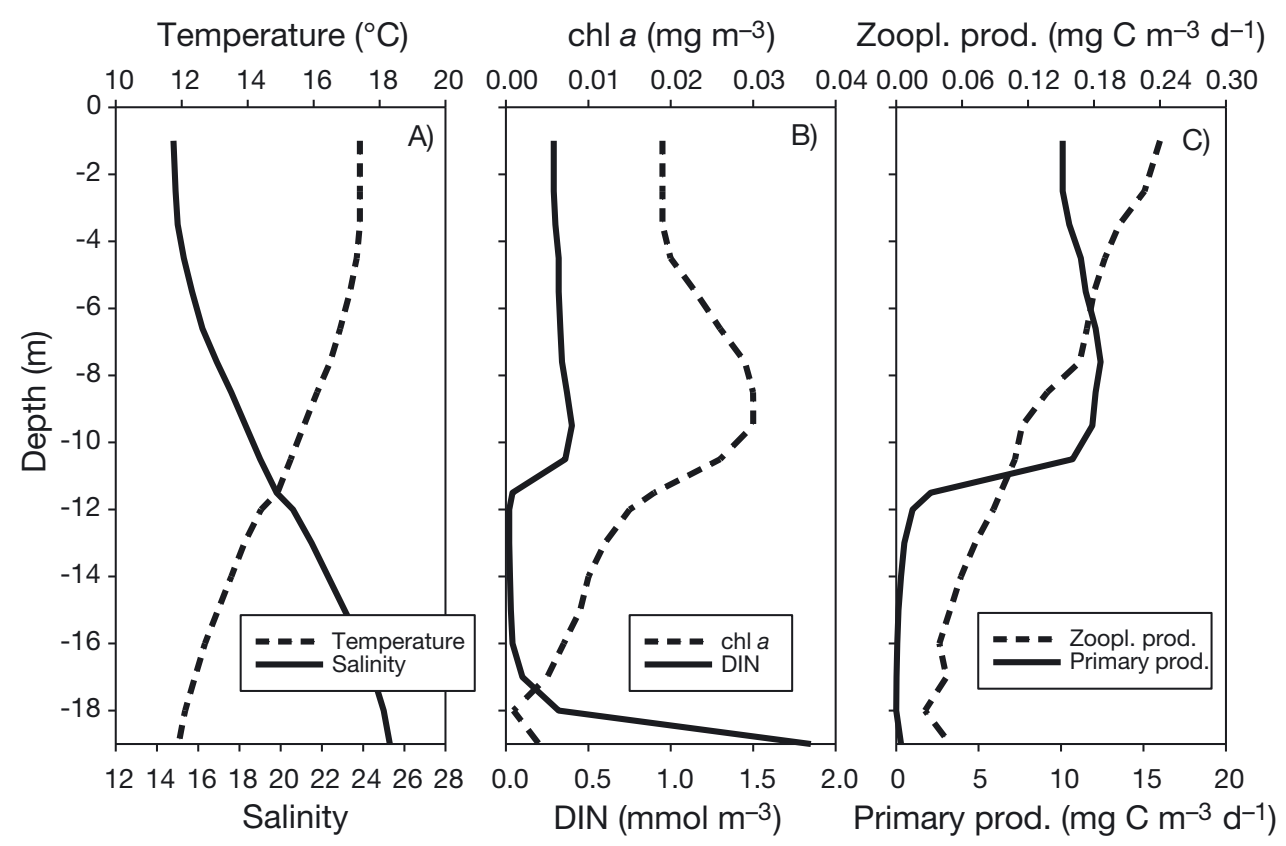

\section{Transport of nutrients from the fish farms}

Gross transports of total $\mathrm{N}$ and total $\mathrm{P}$ were higher to the western than to the eastern coastal water areas, and in S100, $42.1 \mathrm{t} \mathrm{N}$ and 4.0 t P were transported to both areas (Table 4). This corresponded to $21 \%(\mathrm{~N})$ and $16 \%(\mathrm{P})$ of total fish waste in S100 (both farms). Net transports of nutrients (i.e. local retention and loss) were about 3 to 10 times lower than gross value and were similar between the 2 areas (Table 4). Gross and net nutrient transports were around 4 times higher in S100 than in S25. Benthic nutrient fluxes from deposited solid fish waste contributed with 11 and $37 \%$ of total $\mathrm{N}$ and $\mathrm{P}$ gross transports, respectively, according to the sensitivity study.

\section{Environmental impacts on the sediment below fish farms}

Seasonally, organic N and P in S25 and S100 increased relative to REF from April to August followed by a gradual decline over time due to resuspension and degradation (Fig. 9). Resuspension of fish waste mainly occurred during the fish production period as organic matter was slowly transferred to the consolidated sediment. Resuspension was lower at Bolsaksen, which led to a higher sediment impact compared to Ballen (Table 5). Hence, the most substantial impact occurred at Bolsaksen in S100 with up to a 90 and $207 \%$ increase of sediment $\mathrm{N}$ and $\mathrm{P}$, respectively (Fig. 9). At the time for a new production period (Day 455), the impact was here reduced to $25 \%(\mathrm{~N})$ and $32 \%(\mathrm{P})$. At Ballen, the impact in S100 was 3 to 6 times lower than for Bolsaksen (Fig. 9). Spatial impact was mainly within the farm area $<400 \mathrm{~m}$ from the cages.

The modelled seasonal sediment-water fluxes of nutrients and oxygen below the farms were highest from September to October (Fig. 6). Phosphate and oxygen fluxes in S25 at Ballen (lowest impact) were similar to observations in 2 fjords during years with oxygen depletion (Fig. 6). The highest impacts on nutrient fluxes were an average 466 to $900 \%$ (April to October) for Bolsaksen in S100 (Table 5). Degradation rates and oxygen consumption were likewise higher at Bolsaksen compared to Ballen in both scenarios (Table 5). Denitrification rates, on the other hand, increased similarly at the 2 sites. Dissimilatory nitrate reduction to ammonium (DNRA) increased more than denitrification rates, with up to $150 \%$ at Ballen and $485 \%$ at Bolsaksen in S100. Suspension feeder biomass increased at Ballen but showed low responses at Bolsaksen in both scenarios. Deposit feeders showed higher responses than suspension feeders at both locations, with the highest changes $(1273 \%)$ at Bolsaksen (Table 5). Spatially for the study area, suspension feeders obtained highest biomass in shallow, productive areas with high advection or mixing of the water column (Fig. S1A). In contrast, deposit feeders showed highest biomass in deeper areas with low bottom currents and accumulation of organic matter from sedimentation, except for the deep areas with frequent hypoxia (Fig. S1B). 

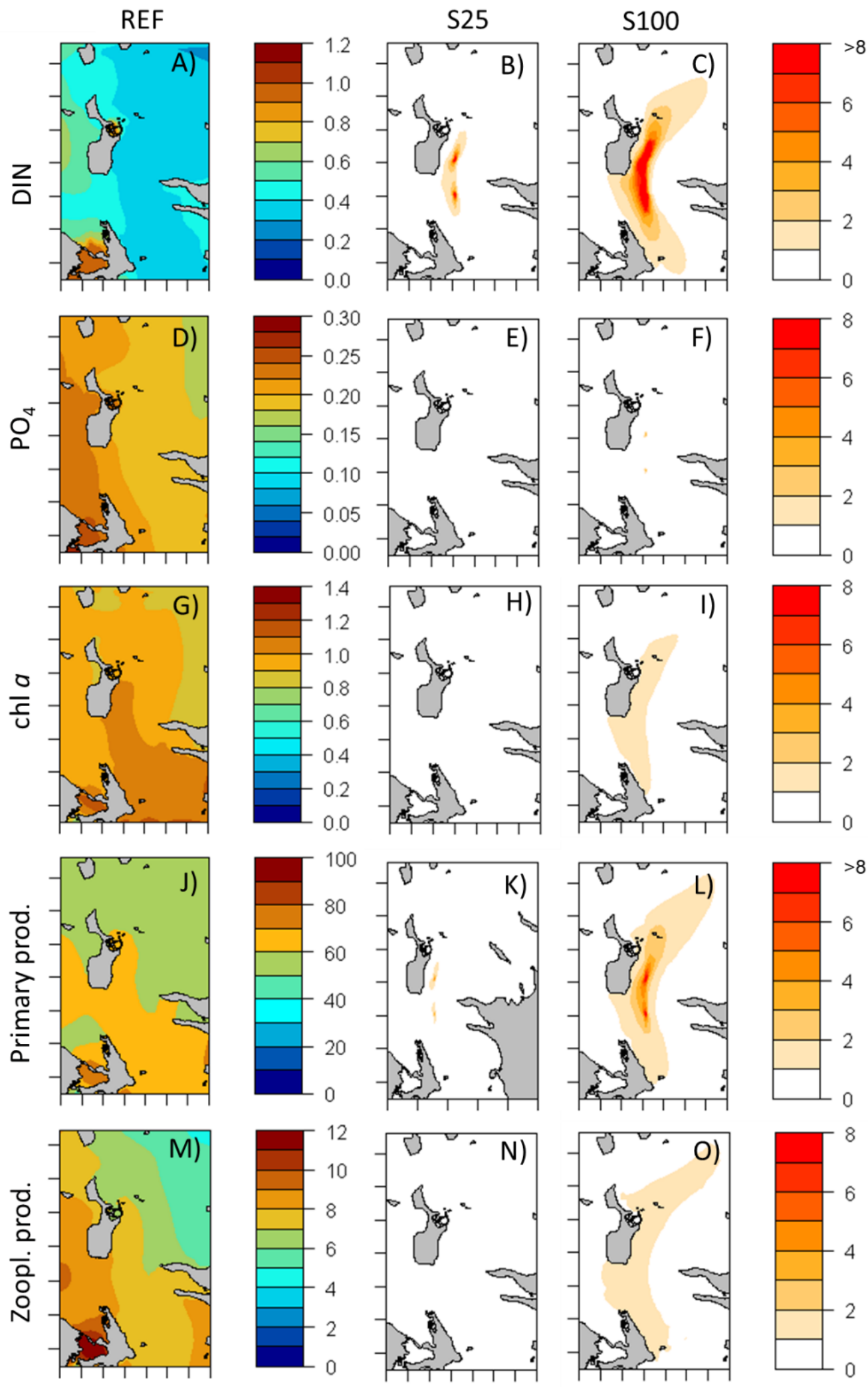

Fig. 8. (A,D,G,J,M) Average values (June to July 2009) for (A) dissolved inorganic nitrogen (DIN) (mmol m-3), (D) $\mathrm{PO}_{4}\left(\mathrm{mmol}^{-3}\right.$ $\left.\mathrm{m}^{-3}\right)$, (G) chl a $\left(\mathrm{mg} \mathrm{m}^{-3}\right)$, (J) primary production $\left(\mathrm{mg} \mathrm{C} \mathrm{m}^{-3} \mathrm{~d}^{-1}\right)$ and $(\mathrm{M})$ zooplankton production $\left(\mathrm{mg} \mathrm{C} \mathrm{m}^{-3} \mathrm{~d}^{-1}\right)$ and the respective percent difference $(\mathrm{B}, \mathrm{E}, \mathrm{H}, \mathrm{K}, \mathrm{N})$ between Scenario $25(\mathrm{~S} 25)$ and reference run $(\mathrm{REF})$ and $(\mathrm{C}, \mathrm{F}, \mathrm{I}, \mathrm{L}, \mathrm{O})$ between $\mathrm{Scenario} 100$ 
Table 3. Monthly (in 2009) maximum change (in units) and percentage of dissolved inorganic nitrogen (DIN), $\mathrm{PO}_{4}$, and chl a concentrations, primary production, Secchi depth, bottom water oxygen, zooplankton biomass and production in S100 relative to REF in the Samsø Belt. The values are from 5 to $6 \mathrm{~m}$ depth except for Secchi depth and bottom oxygen

\begin{tabular}{|c|c|c|c|c|c|c|c|c|c|c|c|c|c|c|c|c|}
\hline \multirow{2}{*}{$\begin{array}{l}\text { Month } \\
\text { April }\end{array}$} & \multirow{2}{*}{$\begin{array}{r}\text { DIN } \\
\left(\mathrm{mmol} \mathrm{m}^{-3}\right) \\
0.15\end{array}$} & \multirow{2}{*}{$\begin{array}{l}\text { N } \\
34 \\
54\end{array}$} & \multicolumn{2}{|c|}{$\begin{array}{c}\mathrm{PO}_{4} \\
\left.(\mathrm{mmol} \mathrm{m})^{-3}\right) \%\end{array}$} & $\begin{array}{r}\mathrm{chl} \\
\left(\mathrm{mg} \mathrm{m}^{-3}\right)\end{array}$ & \multicolumn{3}{|c|}{$\underset{\text { production }}{\text { Primary }} \underset{\left(\mathrm{mg} \mathrm{C} \mathrm{m}^{-3} \mathrm{~d}^{-1}\right) \%}{\%}$} & \multicolumn{2}{|c|}{$\begin{array}{l}\text { Secchi } \\
\text { depth }\end{array}$} & $\begin{array}{r}\text { Bottom } \\
\text { oxygen } \\
\left(\mathrm{mmol} \mathrm{m}^{-3}\right)\end{array}$ & $\%$ & \multicolumn{2}{|c|}{$\begin{array}{c}\text { Zooplankton } \\
\text { biomass } \\
\left(\mathrm{mg} \mathrm{C} \mathrm{m}^{-3}\right) \%\end{array}$} & \multicolumn{2}{|c|}{$\begin{array}{c}\text { Zooplankton } \\
\text { production } \\
\left(\mathrm{mg} \mathrm{C} \mathrm{m}^{-3} \mathrm{~d}^{-1}\right) \%\end{array}$} \\
\hline & & & 0.005 & 2.5 & 0.02 & 1.1 & 7.9 & 13.5 & -0.005 & -0.1 & -0.0 & -0.0 & 0.05 & 0.1 & 0.07 & 1.1 \\
\hline May & 0.15 & 51 & 0.005 & 2.6 & 0.01 & 0.9 & 5.9 & 10.0 & -0.006 & -0.1 & -0.2 & -0.1 & 0.09 & 0.2 & 0.07 & 1.1 \\
\hline June & 0.16 & 56 & 0.005 & 2.4 & 0.02 & 1.7 & 7.9 & 12.3 & -0.007 & -0.1 & -0.4 & -0.2 & 0.16 & 0.4 & 0.11 & 1.7 \\
\hline July & 0.32 & 89 & 0.009 & 4.7 & 0.03 & 2.0 & 11.5 & 13.0 & -0.014 & -0.2 & -0.7 & -0.3 & 0.24 & 0.4 & 0.19 & 1.8 \\
\hline August & 0.15 & 33 & 0.005 & 2.2 & 0.01 & 1.0 & 5.2 & 6.3 & -0.005 & -0.1 & -1.1 & -0.6 & 0.16 & 0.2 & 0.11 & 1.0 \\
\hline September & er 0.15 & 23 & 0.005 & 2.0 & 0.01 & 0.4 & 1.5 & 2.7 & -0.005 & -0.1 & -0.9 & -0.5 & 0.12 & 0.3 & 0.05 & 0.7 \\
\hline October & 0.06 & 8 & 0.002 & 0.7 & 0.00 & 0.2 & 0.6 & 1.2 & 0.000 & -0.0 & -1.0 & -0.5 & 0.03 & 0.2 & 0.02 & 0.3 \\
\hline November & r $\quad 0.01$ & 0 & 0.003 & 0.1 & 0.00 & 0.0 & 0.1 & 0.3 & 0.000 & -0.0 & -0.8 & -0.4 & 0.01 & 0.0 & 0.00 & 0.0 \\
\hline December & r $\quad 0.00$ & 0 & 0.001 & 0.0 & 0.00 & 0.0 & 0.0 & 0.0 & 0.000 & -0.0 & -0.9 & -0.4 & 0.00 & 0.0 & 0.00 & 0.0 \\
\hline
\end{tabular}

\section{DISCUSSION}

\section{Effects on water quality in open waters}

The seasonal response in water quality (nutrients, chl $a$, pelagic production) followed the seasonal patterns of added fish feed at the 2 offshore fish farms, with the highest effects in June and July (Fig. 3, Table 3). However, the nutrient inputs and related changes in water quality were rapidly diluted over time, leaving no trace 1 mo after the fish production period (Table 3). Surface DIN concentrations (5 to $6 \mathrm{~m}$ ) showed the highest responses in magnitude (up to $89 \%$ close to the farms), with a gradual dilution up to $30 \mathrm{~km}$ from the nearest farm (S100, Fig. 8C). The spatial impact range of DIN was similar to that of freshwater DIN inputs, with a gradual dilution up to 20 to $25 \mathrm{~km}$ from the coast (Maar et al. 2016). The impact on surface $\mathrm{PO}_{4}$ concentrations was lower than for DIN concentrations probably due to relative higher background concentrations (Sarà 2007, Tsagaraki et al. 2011). Nutrients from fish farms are added during the productive season for phytoplankton, where growth is limited by available nitrogen (Richardson \& Christoffersen 1991). The addition of more nutrients

Table 4. Difference in gross and net transports of total $\mathrm{N}$ and total P from the offshore fish farms to the western and eastern coastal water areas relative to REF

\begin{tabular}{|c|c|c|c|c|c|c|c|c|}
\hline \multirow[t]{3}{*}{ Scenario } & \multicolumn{4}{|c|}{$\longrightarrow$ West } & \multicolumn{4}{|c|}{$\longrightarrow$ East } \\
\hline & \multicolumn{2}{|c|}{ Total N (t) } & \multicolumn{2}{|c|}{ Total P (t) } & \multicolumn{2}{|c|}{ Total N (t) } & \multicolumn{2}{|c|}{ Total P (t) } \\
\hline & Gross & Net & Gross & Net & Gross & Net & Gross & Net \\
\hline S25 & 7.6 & 0.8 & 0.76 & 0.09 & 2.9 & 0.9 & 0.25 & 0.09 \\
\hline $\mathrm{S} 100$ & 30.4 & 3.3 & 3.00 & 0.34 & 11.7 & 3.4 & 1.00 & 0.35 \\
\hline
\end{tabular}

from the fish farms stimulated primary production with the same horizontal distribution as for DIN (Fig. 8L), whereas chl a concentrations showed lower responses (Fig. 8I). Low responses of chl a concentrations to nutrient inputs from fish farms have previously been attributed to rapid dilution of nutrients by currents exceeding the growth rate of phytoplankton (Sarà 2007, Skogen et al. 2009). However, in oligotrophic waters, there is a transfer of nutrients from fish farms to higher trophic layers by phytoplankton grazers, keeping the phytoplankton biomass at very low levels (Pitta et al. 2009). The low responses of chl a concentrations in the present study are probably a combination of dilution due to high current speeds and grazing by zooplankton, since both primary production and zooplankton production increased in the area (Table 3, Fig. 8L,O). Hence, nutrient inputs from fish farms and the resulting increase in pelagic production contribute to bottom-up cascading effects on the pelagic food web (Bonsdorff et al. 1997). Changes in bottom water oxygen, on the other hand, was not detectable due to dilution by bottom currents and bottom mixing in accordance with previous studies (Skogen et al. 2009, Wild-Allen et al. 2010, á Norði et al. 2011). The found changes (S100) in DIN concentrations were higher than the natural day-to-day variability (16 to $26 \%$ in July), whereas changes in $\mathrm{PO}_{4}$ and chl a concentrations $(<5 \%)$ were lower than the natural variability $(9$ to $24 \%$ ) in the study area (Table 3 , Fig. 5). The impact was even lower in magnitude and spatially for the smaller farms (S25), with 4 times less nutrient addition than the standard offshore farms (S100) (Fig. 8). 

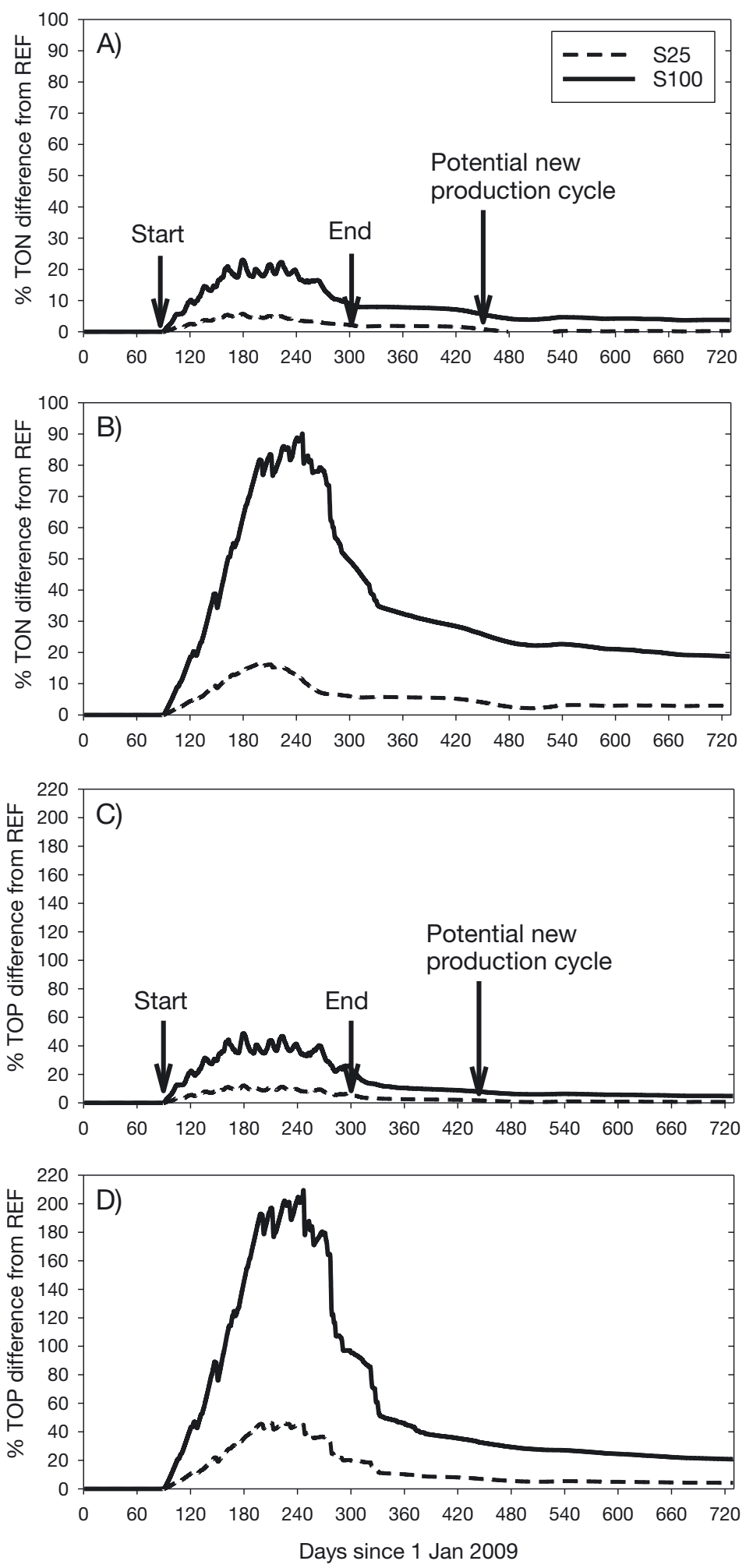

Fig. 9. Average difference below the fish cages in sediment total organic nitrogen (TON) at (A) Ballen and (B) Bolsaksen and total organic phosphorus (TOP) at (C) Ballen and (D) Bolsaksen between the reference run (REF) and each of the scenarios (S25, S100). Arrows indicate the start, end and potential new start the following year of the fish production
Whereas the ecological relevance of changes lower than the natural variability may seem insignificant in most areas, it may still contribute to the eutrophication effects in sensitive areas like the inner Danish waters (Christensen et al. 2000, Riemann et al. 2016).

\section{Effects on coastal waters and protected habitats}

Future finfish farms are planned to be located offshore due to an assumed higher dispersal of waste products by surface currents and less impact on coastal water areas (Holmer 2010). However, this study shows that $42.1 \mathrm{t} \mathrm{N} \mathrm{(21 \%} \mathrm{of}$ total $\mathrm{N})$ and $4.00 \mathrm{t} \mathrm{P}(16 \%$ of total P) released from the 2 hypothetical offshore fish farms were (gross) transported into the coastal water areas (S100, Table 4). Net transports (i.e. local retention and loss) were much lower and similar between the 2 coastal water areas, corresponding to $3-4 \%$ of the released nutrients in S100. However, we consider gross nutrient transports as a more correct estimate of the impact than net transports, because the inflowing nutrients affect the ecosystem through, for example, phytoplankton uptake and recycling before leaving the area again (Timmermann et al. 2010). Nevertheless, the model results of the added nutrient loads gave only minor increases in DIN concentrations, chl a concentrations and primary and secondary production and no changes in Secchi depths or bottom hypoxia in the coastal water areas (Fig. 8). A good ecological status has not yet been achieved for these areas, and further reductions of nutrient loads from a variety of sources, e.g. freshwater nutrient inputs, atmospheric deposition and transports from adjacent sea areas, are required (Schernewski et al. 2015, Maar et al. 2016, HELCOM 2017). Hence, additional nutrient enrichment due to far-field transports of nutrients from offshore fish farms counteracts this requirement and must remain a concern when trying to improve the ecological status.

According to the EU Habitats Directive, favourable conservation should be obtained for habitats in the different Natura 2000 sites. At present, there is no operational system in force for assessing the conservation status of protected habitats in Denmark. However, it is obvious that the nutrient regime is important for the 
Table 5. Average sediment organic content $\left(\mathrm{mol} \mathrm{m}^{-2}\right)$ of $\mathrm{C}, \mathrm{N}$, and $\mathrm{P}$; nutrient fluxes $\left(\mathrm{mmol} \mathrm{m}^{-2} \mathrm{~d}^{-1}\right)$ and oxygen consumption $\left(\mathrm{mmol} \mathrm{O}_{2} \mathrm{~m}^{-2} \mathrm{~d}^{-1}\right)$; denitrification rate $\left(\mathrm{mmol} \mathrm{N} \mathrm{m} \mathrm{d}^{-2} \mathrm{~d}^{-1}\right.$ ), dissimilatory nitrate reduction to ammonium (DNRA) (mmol $\mathrm{N} \mathrm{m}^{-2}$ $\left.\mathrm{d}^{-1}\right)$, and oxygen concentration $\left(\mathrm{mmol} \mathrm{O}_{2} \mathrm{~m}^{-3}\right)$; sedimentation of detritus and diatoms $\left(\mathrm{mg} \mathrm{N} \mathrm{m}^{-2} \mathrm{~d}^{-1}\right)$; and benthic suspension feeder and deposit feeder biomass $\left(\mathrm{mmol} \mathrm{C} \mathrm{m}^{-2}\right.$ ) during the production period (April to October) at Ballen and Bolsaksen in the reference run (REF) and scenarios (S25, S100). The percentage differences between scenarios and REF are shown in parentheses

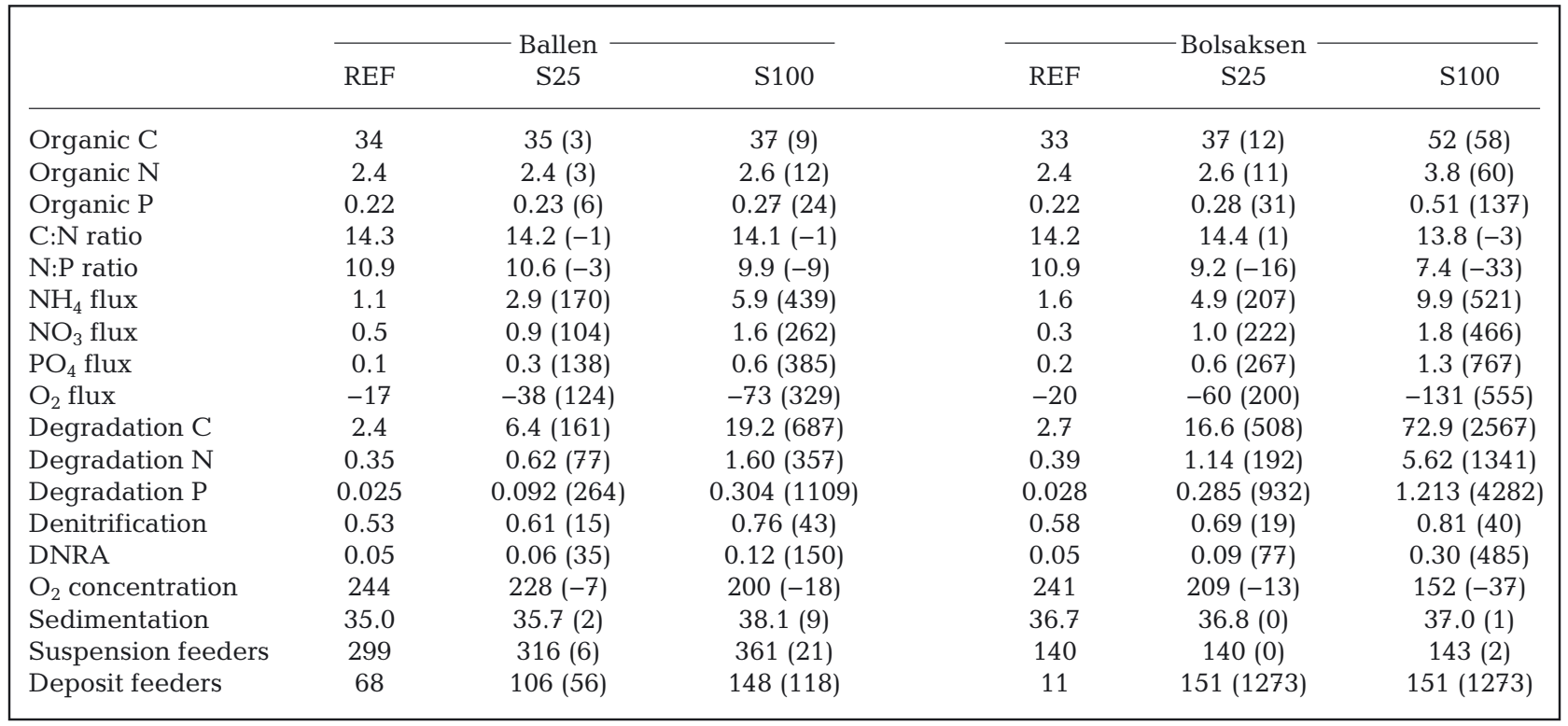

conservation status in the Danish marine areas (Riemann et al. 2016). This suggests that several of the protected sites south and northeast of the fish farms (Figs. 1A \& 8) will presumably be exposed to, and possibly negatively affected by, the increased loads of nutrients from the fish production.

\section{Sediment impacts below fish farms}

The model results show that benthic impact below the fish cages would be higher at Bolsaksen than at Ballen because bottom currents, and hence resuspension, were lowest at Bolsaksen (Fig. 9). Previous field and modelling studies also showed that resuspension spreads solid waste to a larger area and thereby reduces the local impact (Chamberlain \& Stucchi 2007, Bannister et al. 2014, Broch et al. 2017). Maximum organic sediment increase at Bolsaksen in S100 (Table 5) was within the range of reported values below fish farms (Holmer \& Kristensen 1992, á Norði et al. 2011, Valdemarsen et al. 2012). In addition, the sediment did not recover between the fish production periods (5 mo), where the organic $\mathrm{N}$ and P content was 25 and $32 \%$ higher, respectively, than reference conditions. Overloading of the assimilation capacity of the sediments may inhibit degradation processes and accumulate organic matter over time in low-current $\left(\approx 0.02 \mathrm{~m} \mathrm{~s}^{-1}\right)$ environments (Valdemarsen et al. 2012). In contrast, the sediment seemed to recover faster after 5 mo for a smaller farm size (S25) or at Ballen with higher resuspension (Fig. 9). However, the deposited organic matter will still accumulate over time (1 to $5 \% \mathrm{yr}^{-1}$ for $\mathrm{N}$ and 2 to $7 \% \mathrm{yr}^{-1}$ for P), although at a lower rate than for Bolsaksen S100. A solution to minimise the benthic impact could be to increase the fallow period, e.g. to more than $1 \mathrm{yr}$, or to optimise the farm design, e.g. with respect to spatial arrangements. In Danish coastal areas, sediment samples taken below 7 fish farms after 3 to 5 mo of recovery showed no significant accumulation of $\mathrm{N}$, whereas the $\mathrm{P}$ content increased below 4 of the farms (Møhlenberg 2013). Field studies from New Zealand, the Faroe Islands and Norway found a recovery of the sediment within 1 to 6 mo in areas with higher current speeds, depending on the size of the impact (á Norði et al. 2011, Bannister et al. 2014, Keeley et al. 2015). Hence, with respect to marine spatial planning, the location and size of the fish farm together with the fallow period are major factors for the longterm sustainability of fish farms, especially in the inner Danish waters sensitive to eutrophication.

Deposit feeders benefitted from the increased sedimentation of solid fish waste, but only to a certain level, whereas the lower oxygen conditions induced higher mortality in the model (Table 5). Previous field 
studies also found that organic enrichment to a certain level increased benthic fauna density and biomass below fish farms, often dominated by more pollutant-tolerant species (Kutti et al. 2007, Holmer 2010, Valdemarsen et al. 2015). The enrichment, on the other hand, may lead to hypoxia with hydrogen sulphide release, with detrimental effects on the benthic fauna (Keeley et al. 2015, Valdemarsen et al. 2015). The relative accumulation of organic matter between S100 and S25 was higher at Bolsaksen (up to 6 times) compared to Ballen (4 times), because the deposit feeders ingested less under the hypoxic conditions in S100 (Table 5). Hence, it is important to choose farming sites with high water currents to maintain a well-functioning macrofauna community, which stimulates the degradation of fish waste and mitigates local negative effects (Keeley et al. 2015, Valdemarsen et al. 2015, Zhulay et al. 2015).

Sediment nutrient and oxygen fluxes were highest (up to 9-fold increase) at Bolsaksen S100, with the highest organic enrichment (Table 5). Nutrients were released from the sediment during and after the fish production period, whereas there was an uptake of oxygen from the water column (Fig. 6). Fluxes were highest in September, with the highest organic enrichment and temperatures, and several times higher than observed in the nearby fjords (Fig. 6). Oxygen consumption was reported from 40 to $278 \mathrm{mmol} \mathrm{O}_{2}$ $\mathrm{m}^{-2} \mathrm{~d}^{-1}$ below a coastal Danish farm and up to 6 times greater than at the reference stations (Christensen et al. 2000), which agrees with with our average estimates of 2 to 7 times increase in S25 and S100 during the fish production period (Table 5). Christensen et al. (2000) also reported ammonium fluxes from 1 to $12 \mathrm{mmol} \mathrm{m} \mathrm{m}^{-2} \mathrm{~d}^{-1}$ and phosphate fluxes from 1 to $5 \mathrm{mmol} \mathrm{m} \mathrm{m}^{-2} \mathrm{~d}^{-1}$ below the fish farm, which is similar to our average estimates in S25 and S100 (Table 5). Nutrients from regenerated solid organic fish waste in the sediment increased in bottom waters (Fig. 7B) and contributed $11 \% \mathrm{~N}$ and $37 \% \mathrm{P}$ of total gross nutrient transports into the coastal water areas. A study from the Mediterranean Sea also showed that regenerated nutrients from solid fish waste may be transported far away from the fish farm (Pitta et al. 2005). Denitrification rates increased less than DNRA due to the lower sediment oxygen levels in S100 in accordance with the study by Christensen et al. (2000). The removal of $\mathrm{N}$ below the fish cages $\left(2 \mathrm{~km}^{2}\right)$ due to denitrification (210 production days) corresponded to $<2 \%$ of the total $\mathrm{N}$ farm input. The model-estimated denitrification rates were within the measured range from 0.02 to $4.00 \mathrm{mmol} \mathrm{m} \mathrm{m}^{-2} \mathrm{~d}^{-1}$ below a Danish fish farm, where $0.1 \%$ of the addi- tional $\mathrm{N}$ input was removed by denitrification (Christensen et al. 2000). Hence, most of the added $\mathrm{N}$ to the sediment will be available for primary production after remineralisation (Christensen et al. 2000).

\section{Model validation and uncertainties}

Model validation of the pelagic variables showed an overall good performance compared to data from 3 monitoring stations (Table 2). Secchi depths were not significantly correlated with data at Romsø stn, but here only direct Secchi depth measurements were available. These are known to be less precise than $k_{\mathrm{d}}$ measurements converted to Secchi depths (Carstensen 2010) and may explain some of the deviations. Previous studies showed that less than $30 \%$ of the light attenuation is caused directly by chl $a$, the rest being attributed to coloured dissolved organic matter (CDOM), detritus and seawater (Timmermann et al. 2010). Light attenuation due to CDOM is not explicitly described in the model but correlates with salinity (Maar et al. 2011). Hence, a more detailed description of CDOM would probably improve the model performance with respect to estimations of Secchi depths.

Sediment variables are more difficult to validate due to lack of consistent monitoring data. Sediment fluxes of nutrients and oxygen in REF were therefore compared with the only available monitoring data from 3 previous years (1999, 2000 and 2003) from 2 shallow fjords (Fig. 6). However, nutrient fluxes were overestimated by the model during February to May. Field work showed that there was net uptake in the sediment during this period due to assimilation by benthic algae in shallow waters (Christensen et al. 2000), which is not described in our model. Likewise, there was an efflux of oxygen during March and April in the measurements due to benthic primary production not covered by the model. However, benthic primary production is not expected to occur at the deeper farm locations and would not influence our results below the farms. The 3 monitoring years were characterised by strong hypoxia events (Hansen 2013) and therefore showed higher oxygen consumptions and higher phosphate and ammonium fluxes during summer than for the model year 2009 without severe hypoxia. Although the compared years are different with respect to oxygen levels, the model seems to behave as expected with regard to the seasonal sediment fluxes.

Sediment organic carbon and nitrogen content at the farm sites in REF (Table 5) were within the range 
of previously reported values from the area of 20 to $80 \mathrm{~mol} \mathrm{C} \mathrm{m}^{-2}$ and 1.8 to $7.5 \mathrm{~mol} \mathrm{~N} \mathrm{~m}^{-2}$ (Rysgaard et al. 2001). Denitrification rates and sedimentation rates of detritus and diatoms (Table 5, REF) were similar to reported values of 0.01 to $1.03 \mathrm{mmol} \mathrm{N} \mathrm{m} \mathrm{N}^{-2} \mathrm{~d}^{-1}$ and $33.5 \pm 2.7 \mathrm{mg} \mathrm{N} \mathrm{m}^{-2} \mathrm{~d}^{-1}$, respectively, from the area (Rysgaard et al. 2001, Jørgensen et al. 2014). The estimated spatial distributions of suspension feeders and deposit feeders were related to the different hydrodynamic regimes within the area (Fig. S1), as reported in previous studies (Heip et al. 1995, Josefson \& Conley 1997, Josefson \& Rasmussen 2000). The average biomass below the fish farms (Table 5, REF) were close to the observed values of suspension feeders of 0.4 to $14.5 \mathrm{~g} \mathrm{C} \mathrm{m}^{-2}$ and deposit feeders of 0.5 to $1.9 \mathrm{~g} \mathrm{C} \mathrm{m}^{-2}$ from the area (Maar \& Hansen 2011, Hansen 2012). Hence, model results of the sediment variables in REF are consistent with monitoring data and literature values from the area.

In the scenarios, hypothetical fish farms were inserted at 2 potential locations in the Samsø Belt area but without any local sediment and benthos data from the 2 locations. For a more thorough investigation of the impact from fish farms, more knowledge about the local sediment characteristics (e.g. organic and inorganic contents, fluxes) and resuspension thresholds would be needed. Detailed data on benthos biomass are also lacking from the area and below the farms. An overestimation of the benthos biomass by the model would overestimate degradation rates of organic matter below fish farms and, hence, underestimate benthic impact by solid fish waste. For the nutrient input from fish farms, there is an uncertainty in the size distribution of the particular organic waste. We assumed that all the organic material settled to the bottom immediately due to the reported high sinking velocities. However, some of the material may be fragmented into smaller particles that may sink slower and hence spread to a larger area (Magill et al. 2006). New experiments, e.g. using settling columns and particle tracking software, could help to resolve the particle size distributions and related sinking rates of faecal material collected below the farms. Another issue is that the model did not consider benthic micro- and macroflora, which are important primary producers in shallow areas. Benthic vegetation stabilises the surface sediment, affects nutrient and oxygen fluxes and is sensitive to changes in light attenuation, e.g. due to fish farming. Further, sediment chemistry was simplified with respect to only using 1 sediment layer and ignoring some of the chemical processes in the anoxic layers. Nevertheless, the model results of benthic impacts (organic enrichment and sediment fluxes) below fish farms were in accordance with previous field studies as described in the previous subsection. However, future model developments should focus on benthic vegetation and more detailed sediment chemistry.

\section{Conclusions}

An important question is the extent to which offshore fish farms (in this study, 4 to $10 \mathrm{~km}$ from the coast) would affect the environmental quality of inner Danish waters. In our model, the effects of the 2 hypothetical offshore fish farms on the environment did not lead to phytoplankton blooms, reduced Secchi depths or bottom hypoxia. DIN concentrations and primary production increased in open waters near the farms during the production period, but there were no traces 1 mo after the end of the fish production period. Most of the nutrients from the fish farms remained in open waters, and the major plume was swept over several Natura 2000 sites. Although no national monitoring system to assess the conservation status of protected habitats in Natura 2000 sites exists to date, the potential impacts of fish farming need to be considered when deciding on the location of production sites. In our model, sediment content and nutrient fluxes increased locally below the fish farms, especially at the site with lowest resuspension, and the released nutrients were transported into coastal waters. The sediment below the farms did not recover between production periods, and thus the accumulation of organic matter over time may lead to local hypoxia and sulphide release. It is therefore important to place new fish farms in areas with enough resuspension for dispersal and to optimise the farm design and fallow period to minimise the benthic impact.

There was a gross transport of nutrients into the coastal water areas corresponding to $21 \% \mathrm{~N}$ and $16 \% \mathrm{P}$ of the farm inputs. However, the model results showed only minor increases of, for example, DIN and chl a concentrations due to this nutrient addition. It was not possible to evaluate the extent to which such changes will affect the eutrophication status of the coastal marine environment, e.g. change the eutrophication status negatively according to the WFD. HELCOM (2017) recently reported an updated version of the integrated status assessment of eutrophication in the Baltic Sea, including the inner Danish waters examined in this study. With few exceptions, the assessment demonstrated moderate 
to bad status for the Danish waters. These results call for further reductions in the nutrient loads to Danish marine waters to improve their ecological status. Hence, the transport of nutrient loads from offshore fish farms to coastal water areas, and their impact, is of concern. Recently, the Danish Ministry of Environment and Food proposed a plan for a gradual increase in marine fish farms in Denmark (Miljø og Fødevareministeriet 2015). New fish farms, however, shall include measures to compensate for the released nutrients from the fish farms, e.g. line production of blue mussels (LOV nr. 680 af 08/06/2017), but the exact conditions are still under implementation.

Acknowledgements. The work was supported by the EU grants Optimisation of mussel mitigation cultures for fish feed in the Baltic Sea (BONUS OPTIMUS, Blue Baltic 2017-2020) and Towards Sustainable Governance of Baltic Marine Space (BONUS BALTSPACE, Sustainable Ecosystem Services 2015-2018). We thank Anne Johanne Tang Dalsgaard for providing data from the fish waste production model and Jonas Koefoed Rømer for providing graphical input. We also thank 3 anonymous referees for their constructive comments on a previous version of the manuscript.

\section{LITERATURE CITED}

Allen JI, Holt JT, Blackford J, Proctor R (2007) Error quantification of a high-resolution coupled hydrodynamicecosystem coastal-ocean model: part 2. Chlorophyll-a, nutrients and SPM. J Mar Syst 68:381-404

Andersson L, Rydberg L (1988) Trends in nutrient and oxygen conditions within the Kattegat: effects of local nutrient supply. Estuar Coast Shelf Sci 26:559-579

á Norði GA, Glud RN, Gaard E, Simonsen K (2011) Environmental impacts of coastal fish farming: carbon and nitrogen budgets for trout farming in Kaldbaksfjøður (Faroe Islands). Mar Ecol Prog Ser 431:223-241

Bannister RJ, Valdemarsen T, Hansen PK, Holmer M, Ervik A (2014) Changes in benthic sediment conditions under an Atlantic salmon farm at a deep, well-flushed coastal site. Aquacult Environ Interact 5:29-47

Berg P, Poulsen JW (2012) Implementation details for HBM. Tech Rep No. 12-11, DMI, Copenhagen

* Bonsdorff E, Blomqvist EM, Mattila J, Norkko A (1997) Coastal eutrophication: causes, consequences and perspectives in the archipelago areas of the northern Baltic Sea. Estuar Coast Shelf Sci 44:63-72

Bostock J, McAndrew B, Richards R, Jauncey K and others (2010) Aquaculture: global status and trends. Philos Trans R Soc Lond B Biol Sci 365:2897-2912

Brandt J, Christensen JH, Frohn LM, Palmgren F, Berkowicz R, Zlatev Z (2001) Operational air pollution forecasts from European to local scale. Atmos Environ 35:S91-S98

Broch OJ, Daae RL, Ellingsen IH, Nepstad R, Bendiksen EÅ, Reed JL, Senneset G (2017) Spatiotemporal dispersal and deposition of fish farm wastes: a model study from central Norway. Front Mar Sci 4:1-15

Carstensen J (2010) Censored data regression: statistical methods for analyzing Secchi transparency in shallow systems. Limnol Oceanogr Methods 8:376-385

* Chamberlain J, Stucchi D (2007) Simulating the effects of parameter uncertainty on waste model predictions of marine finfish aquaculture. Aquaculture 272:296-311

* Christensen PB, Rysgaard S, Sloth NP, Dalsgaard T, Schwærter S (2000) Sediment mineralization, nutrient fluxes, denitrification and dissimilatory nitrate reduction to ammonium in an estuarine fjord with sea cage trout farms. Aquat Microb Ecol 21:73-84

* Christiansen C, Gertz F, Laima MJC, Lund-Hansen LC, Vang T, Jürgensen C (1997) Nutrient $(P, N)$ dynamics in the southwestern Kattegat, Scandinavia sedimentation and resuspension effects. Environ Geol 29:66-77

* Cromey CJ, Nickell TD, Black KD (2002) DEPOMODmodelling the deposition and biological effects of waste solids from marine cage farms. Aquaculture 214:211-239

Dalsgaard AJT, Pedersen PB (2016) Produktionsbidrag og dambrugsmodel: manual og modelforudsætninger. Rapport nr. 309-2016, DTU Aqua, Hirsthals

*Dalsgaard J, Pedersen PB (2011) Solid and suspended/dissolved waste $(\mathrm{N}, \mathrm{P}, \mathrm{O})$ from rainbow trout (Oncorynchus mykiss). Aquaculture 313:92-99

* Dalsgaard T, Krause-Jensen D (2006) Monitoring nutrient release from fish farms with macroalgal and phytoplankton bioassays. Aquaculture 256:302-310

* Douvere F (2008) The importance of marine spatial planning in advancing ecosystem-based sea use management. Mar Policy 32:762-771

Duarte CM, Holmer M, Olsen Y, Soto D and others (2009) Will the oceans help feed humanity? Bioscience 59:967-976

European Commission (2012) Blue growth: opportunities for marine and maritime sustainable growth. Communication from the commission to the European parliament, the council, the European economic and social committee and the committee of the regions. Publ Off Eur Union, Luxembourg. http://eur-lex.europa.eu/legal-content/EN/ ALL/?uri=CELEX:52012DC0494

FAO (Food and Agriculture Organization of the United Nations) (2016) The state of world fisheries and aquaculture 2016. Contributing to food security and nutrition for all. FAO, Rome

Ferreira JG, Saurel C, Silva J, Nunes JP, Vazquez F (2014) Modelling of interactions between inshore and offshore aquaculture. Aquaculture 426-427:154-164

Ganaiger E, Bitterlich G (1984) Proximate biochemical composition and caloric content calculated from elemental CHN analysis: a stoichiometric concept. Oecologia 62: 289-298

*Hadley S, Wild-Allen K, Johnson C, Macleod C (2016) Quantification of the impacts of finfish aquaculture and bioremediation capacity of integrated multi-trophic aquaculture using a 3D estuary model. J Appl Phycol 28: 1875-1889

Hansen JW (ed) (2012) Marine områder 2011. NOVANA. Videnskabelig rapport nr. 34, DCE-Nationalt Center for Miljø og Energi, Aarhus Universitet, Roskilde (in Danish with English summary)

Hansen JW (ed) (2013) Marine områder 2012. NOVANA. Videnskabelig rapport nr. 77, DCE-Nationalt Center for Miljø og Energi, Aarhus Universitet, Roskilde (in Danish with English summary)

Heip CHR, Goosen NK, Herman PMJ, Kromkamp JC, Middelburg JJ, Soetaert KER (1995) Production and consumption of biological particles in temperate tidal estuar- 
ies. Oceanogr Mar Biol Annu Rev 33:1-149

HELCOM (Helsinki Commission) (2013) Summary report on the development of revised maximum allowable input (MAI) and updated country allocated reduction targets (CART) of the Baltic Sea Action Plan. Baltic Marine Environment Protection Commission, Helsinki. http://www. helcom.fi/Documents/Ministerial2013/Associated \% 20 documents/Supporting/Summary\%20report \%20on $\% 20$ MAI-CART.pdf

HELCOM (2017) First version of the 'State of the Baltic Sea' report-June 2017-to be updated in 2018. Baltic Marine Environment Protection Commission, Helsinki. http:// stateofthebalticsea.helcom.fi/

Holmer M (2010) Environmental issues of fish farming in offshore waters: perspectives, concerns and research needs. Aquacult Environ Interact 1:57-70

Holmer M, Kristensen E (1992) Impact of marine fish farming on metabolism and sulfate reduction of underlying sediments. Mar Ecol Prog Ser 80:191-201

Holmer M, Argyrou M, Dalsgaard T, Danovaro R and others (2008) Effects of fish farm waste on Posidonia oceanica meadows: synthesis and provision of monitoring and management tools. Mar Pollut Bull 56:1618-1629

Jansen DL, Lundqvist DP, Christiansen C, Lund-Hansen LC, Balstrom T, Leipe T (2003) Deposition of organic matter and particulate nitrogen and phosphorus at the North Sea-Baltic Sea transition-a GIS study. Oceanologia 45: 283-303

Jørgensen L, Markager S, Maar M (2014) On the importance of quantifying available nitrogen instead of total nitrogen. Biogeochemistry 117:455-472

Josefson AB, Conley DJ (1997) Benthic response to a pelagic front. Mar Ecol Prog Ser 147:49-62

Josefson AB, Rasmussen B (2000) Nutrient retention by benthic macrofaunal biomass of Danish estuaries: importance of nutrient load and residence time. Estuar Coast Shelf Sci 50:205-216

Kaas H, Birkeland MJ, Møhlenberg F (2017) Modellering af lokaliteter til havbrug. Vurdering af miljøeffekter. Standard havbrug A i havbrugszone A. Rapport til NaturErhvervstyrelsen. DHI, Hørsholm

Keeley NB, Forrest BM, Macleod CK (2015) Benthic recovery and re-impact responses from salmon farm enrichment: implications for farm management. Aquaculture 435:412-423

Kiørboe T, Nielsen TG (1994) Regulation of zooplankton biomass and production in a temperate, coastal ecosystem: 1. Copepods. Limnol Oceanogr 39:493-507

Kutti T, Hansen PK, Ervik A, Hoisaeter T, Johannessen P (2007) Effects of organic effluents from a salmon farm on a fjord system. II. Temporal and spatial patterns in infauna community composition. Aquaculture 262:355-366

Larsen J, Maar M, Brüning T, She J, Mohn C (2017) Flexsem: a new method for offline ocean modelling. Tech Rep No. 105, Danish Centre for Environment and Energy, Roskilde

Lyngsgaard MM, Markager S, Richardson K (2014) Changes in the vertical distribution of primary production in response to land-based nitrogen loading. Limnol Oceanogr 59:1679-1690

* Maar M, Hansen JLS (2011) Increasing temperatures change pelagic trophodynamics and the balance between pelagic and benthic secondary production in a water column model of the Kattegat. J Mar Syst 85:57-70

* Maar M, Timmermann K, Petersen JK, Gustafsson KE,
Storm LM (2010) A model study of the regulation of blue mussels by nutrient loadings and water column stability in a shallow estuary, the Limfjorden. J Sea Res 64: 322-333

* Maar M, Møller EF, Larsen J, Madsen KS and others (2011) Ecosystem modelling across a salinity gradient from the North Sea to the Baltic Sea. Ecol Modell 222:1696-1711

* Maar M, Rindorf A, Møller EF, Christensen A, Madsen KS, van Deurs M (2014) Zooplankton mortality in 3D ecosystem modelling considering variable spatial-temporal fish consumptions in the North Sea. Prog Oceanogr 124: 78-91

*Maar M, Markager S, Madsen KS, Windolf J, Lyngsgaard MM, Andersen HE, Møller EF (2016) The importance of local versus external nutrient loads for chl $a$ and primary production in the western Baltic Sea. Ecol Model 320:258-272

Magill SH, Thetmeyer H, Cromey CJ (2006) Settling velocity of faecal pellets of gilthead sea bream (Sparus aurata L.) and sea bass (Dicentrarchus labrax L.) and sensitivity analysis using measured data in a deposition model. Aquaculture 251:295-305

Miljø- og Fødevareministeriet (2015) Dansk akvakultur i vækst. Miljø- og Fødevareministeriet, København. http:// mfvm.dk/fileadmin/user_upload/MFVM/Publikationer/ Aftaletekst_Dansk_akvakultur_i_vaekst.pdf

Møhlenberg F (2013) Udredning i forhold til kommende miljøgodkendelser-sedimentundersøgelser ved danske havbrug. Dansk Akvakultur Notat. DHI, Hørsholm

* Naylor RL, Goldburg RJ, Primavera JH, Kautsky N and others (2000) Effect of aquaculture on world fish supplies. Nature 405:1017-1024

Neumann T (2000) Towards a 3D-ecosystem model of the Baltic Sea. J Mar Syst 25:405-419

*Neumann T, Siegel H, Gerth M (2015) A new radiation model for Baltic Sea ecosystem modelling. J Mar Syst 152:83-91

Nielsen P, Saurel C, Dalsgaard AJT (2015) Samtidigt opdræt af blåmuslinger og tang i forbindelse med havbrug. Rapport nr. 297-2015, DTU Aqua, Hirsthals

Petersen DLJ, Hjorth M (ed) (2010) Marine områder 2009. NOVANA. Tilstand og udvikling i miljø- og naturkvaliteten. Faglig rapport nr. 800, Danmarks Miljøundersøgelser, Aarhus Universitet, Roskilde (in Danish with English Summary)

* Petersen ME, Maar M, Larsen J, Møller EF, Hansen PJ (2017) Trophic cascades of bottom-up and top-down forcing on nutrients and plankton in the Kattegat, evaluated by modelling. J Mar Syst 169:25-39

*Piedecausa MA, Aguado-Gimenez F, Garcia-Garcia B, Ballester G, Telfer T (2009) Settling velocity and total ammonia nitrogen leaching from commercial feed and faecal pellets of gilthead seabream (Sparus aurata L. 1758) and seabass (Dicentrarchus labrax L. 1758). Aquacult Res 40:1703-1714

*Pitta P, Apostolaki ET, Giannoulaki M, Karakassis I (2005) Mesoscale changes in the water column in response to fish farming zones in three coastal areas in the eastern Mediterranean Sea. Estuar Coast Shelf Sci 65:501-512

* Pitta P, Tsapakis M, Apostolaki ET, Tsagaraki T, Holmer M, Karakassis I (2009) 'Ghost nutrients' from fish farms are transferred up the food web by phytoplankton grazers. Mar Ecol Prog Ser 374:1-6

Richardson K, Christoffersen A (1991) Seasonal distribution and production of phytoplankton in the southern Katte- 
gat. Mar Ecol Prog Ser 78:217-227

Riemann B, Carstensen J, Dahl K, Fossing $\mathrm{H}$ and others (2016) Recovery of Danish coastal ecosystems after reductions in nutrient loading: a holistic ecosystem approach. Estuaries Coasts 39:82-97

Rouwenhorst RJ, Frank Jzn J, Scheffers WA, van Dijken JP (1991) Determination of protein concentration by total organic carbon analysis. J Biochem Biophys Methods 22:119-128

Rysgaard S, Fossing H, Jensen MM (2001) Organic matter degradation through oxygen respiration, denitrification, and manganese, iron, and sulfate reduction in marine sediments (the Kattegat and the Skagerrak). Ophelia $55: 77-91$

Sarà G (2007) A meta-analysis on the ecological effects of aquaculture on the water column: dissolved nutrients. Mar Environ Res 63:390-408

Schernewski G, Friedland R, Carstens M, Hirt U and others (2015) Implementation of European marine policy: new water quality targets for German Baltic waters. Mar Policy 51:305-321

She J, Berg P, Berg J (2007) Bathymetry impacts on water exchange modelling through the Danish Straits. J Mar Syst 65:450-459

Silva C, Ferreira JG, Bricker SB, DelValls TA, Martin-Diaz ML, Yanez E (2011) Site selection for shellfish aquaculture by means of GIS and farm-scale models, with an emphasis on data-poor environments. Aquaculture 318: 444-457

Skogen MD, Eknes M, Asplin LC, Sandvik AD (2009) Modelling the environmental effects of fish farming in a Norwegian fjord. Aquaculture 298:70-75

Tett P (1998) Parameterising a microplankton model. Napier University, Edinburgh

* Timmermann K, Markager S, Gustafsson KE (2010) Streams or open sea? Tracing sources and effects of nutrient loadings in a shallow estuary with a 3D hydrodynamicecological model. J Mar Syst 82:111-121

Timmermann K, Norkko J, Janas U, Norkko A, Gustafsson

Editorial responsibility: Jonathan Grant,

Halifax, Nova Scotia, Canada
BG, Bonsdorff E (2012) Modelling macrofaunal biomass in relation to hypoxia and nutrient loading. J Mar Syst 105-108:60-69

* Tovar A, Moreno C, Mánuel-Vez MP, García-Vargas M (2000) Environmental impacts of intensive aquaculture in marine waters. Water Res 34:334-342

* Troell M, Joyce A, Chopin T, Neori A, Buschmann AH, Fang JG (2009) Ecological engineering in aquaculturepotential for integrated multi-trophic aquaculture (IMTA) in marine offshore systems. Aquaculture 297:1-9

* Tsagaraki TM, Petihakis G, Tsiaras K, Triantafyllou G and others (2011) Beyond the cage: ecosystem modelling for impact evaluation in aquaculture. Ecol Modell 222: 2512-2523

* Valdemarsen T, Bannister RJ, Hansen PK, Holmer M, Ervik A (2012) Biogeochemical malfunctioning in sediments beneath a deep-water fish farm. Environ Pollut 170: $15-25$

*Valdemarsen T, Hansen PK, Ervik A, Bannister RJ (2015) Impact of deep-water fish farms on benthic macrofauna communities under different hydrodynamic conditions. Mar Pollut Bull 101:776-783

*Wan Z, She J, Maar M, Jonasson L, Baasch-Larsen J (2012) Assessment of a physical-biogeochemical coupled model system for operational service in the Baltic Sea. Ocean Sci 8:683-701

*Wild-Allen K, Herzfeld M, Thompson PA, Rosebrock U, Parslow J, Volkman JK (2010) Applied coastal biogeochemical modelling to quantify the environmental impact of fish farm nutrients and inform managers. J Mar Syst 81:134-147

*Windolf J, Thodsen H, Troldborg L, Larsen SE, Bøgestrand J, Ovesen NB, Kronvang B (2011) A distributed modelling system for simulation of monthly runoff and nitrogen sources, loads and sinks for ungauged catchments in Denmark. J Environ Monit 13:2645-2658

Zhulay I, Reiss K, Reiss H (2015) Effects of aquaculture fallowing on the recovery of macrofauna communities. Mar Pollut Bull 97:381-390

Submitted: August 14, 2017; Accepted: January 21, 2018

Proofs received from author(s): March 20, 2018 